University of Nebraska - Lincoln

DigitalCommons@University of Nebraska - Lincoln

Downflow Limestone Beds for Treatment of Net-Acidic, Oxic, IronLaden Drainage from a Flooded Anthracite Mine, Pennsylvania, USA: 1. Field Evaluation

\author{
Charles A. Cravotta III \\ US Geological Survey, PA Water Science Center, 215 Limekiln Rd, New Cumberland, PA, USA, \\ cravotta@usgs.gov
}

Suzanne J. Ward

USGS PA Water Science Center, New Cumberland, PA 17070, USA

Follow this and additional works at: https://digitalcommons.unl.edu/usgsstaffpub

Part of the Earth Sciences Commons

Cravotta III, Charles A. and Ward, Suzanne J., "Downflow Limestone Beds for Treatment of Net-Acidic, Oxic, Iron-Laden Drainage from a Flooded Anthracite Mine, Pennsylvania, USA: 1. Field Evaluation" (2008). USGS Staff -- Published Research. 292.

https://digitalcommons.unl.edu/usgsstaffpub/292

This Article is brought to you for free and open access by the US Geological Survey at DigitalCommons@University of Nebraska - Lincoln. It has been accepted for inclusion in USGS Staff -- Published Research by an authorized administrator of DigitalCommons@University of Nebraska - Lincoln. 


\title{
Downflow Limestone Beds for Treatment of Net-Acidic, Oxic, Iron-Laden Drainage from a Flooded Anthracite Mine, Pennsylvania, USA: 1. Field Evaluation
}

\author{
Charles A. Cravotta III · Suzanne J. Ward
}

Received: 10 July 2007/Accepted: 21 December 2007/Published online: 6 February 2008

(C) Springer-Verlag 2008

\begin{abstract}
Passive-treatment systems that route acidic mine drainage (AMD) through crushed limestone and/or organic-rich substrates have been used to remove the acidity and metals from various AMD sources, with a wide range of effects. This study evaluates treatment of net-acidic, oxic, iron-laden AMD with limestone alone, and with organicrich compost layered with the limestone. In the fall of 2003, a treatment system consisting of two parallel, 500- $\mathrm{m}^{2}$ downflow cells followed by a $400-\mathrm{m}^{2}$ aerobic settling pond and wetland was installed to neutralize the AMD from the Bell Mine, a large source of AMD and baseflow to the Schuylkill River in the Southern Anthracite Coalfield, in east-central Pennsylvania. Each downflow cell consisted of a lower substrate layer of 1,090 metric tons ( $t$ ) of dolomitic limestone $\left(60 \mathrm{wt} \% \mathrm{CaCO}_{3}\right)$ and an upper layer of $300 \mathrm{t}$ of calcitic limestone (95 wt $\% \mathrm{CaCO}_{3}$ ); one of the downflow cells also included a $0.3 \mathrm{~m}$ thick layer of mushroom compost over the limestone. AMD with $\mathrm{pH}$ of 3.5-4.3, dissolved oxygen of $6.6-9.9 \mathrm{mg} / \mathrm{L}$, iron of $1.9-5.4 \mathrm{mg} / \mathrm{L}$, and aluminum of $0.8-1.9 \mathrm{mg} / \mathrm{L}$ flooded each cell to a depth $0.65 \mathrm{~m}$ above the treatment substrates, percolated through the substrates to underlying, perforated outflow pipes, and then flowed through the aerobic pond and wetland before discharging to the Schuylkill River. Data on the flow rates and chemistry of the effluent for the treatment system indicated substantial neutralization by the calcitic limestone but only marginal effects from the dolomitic limestone or compost. Because of its higher transmissivity, the treatment cell containing only limestone neutralized greater quantities of acidity than the cell containing compost and limestone. On
\end{abstract}

C. A. Cravotta III $(\varangle) \cdot$ S. J. Ward

USGS PA Water Science Center,

New Cumberland, PA 17070, USA

e-mail: cravotta@usgs.gov average, the treatment system removed $62 \%$ of the influent acidity, $47 \%$ of the dissolved iron, $34 \%$ of the dissolved aluminum, and $8 \%$ of the dissolved manganese. Prior to treatment of the Bell Discharge, the Schuylkill River immediately below its confluence with the discharge had $\mathrm{pH}$ as low as 4.1 and supported few, if any, fish. However, within the first year of treatment, the $\mathrm{pH}$ was maintained at values of 5.0 or greater and native brook trout were documented immediately below the treatment system, though not above.

Keywords Coal mine drainage - Passive treatment . Dolomite $\cdot$ Limestone $\cdot$ Compost $\cdot$ Downflow beds

\section{Introduction}

Problem

Acidic mine drainage (AMD) affects the quality and potential uses of streams, rivers, lakes, and ground water supplies in coal and metal mining regions worldwide (Nordstrom 2000; PIRAMID Consortium 2003). More than $8,000 \mathrm{~km}$ of streams in the Appalachian Region of the northeastern USA are designated "fishless" or "supporting few fish" because of degradation by AMD from abandoned coal mines (Herlihy et al. 1990; U.S. Environmental Protection Agency 2006). Acidic pH $(<4.5)$ and elevated concentrations of dissolved sulfate, iron, and other metals are common characteristics of the AMD (Cravotta et al. 1999; Hyman and Watzlaf 1997; Kirby and Cravotta 2005a, b; Rose and Cravotta 1998). For example, in 1999, more than two-thirds of 140 sampled AMD sources in the Bituminous and Anthracite Coalfields of Pennsylvania had net-acidic water quality and 
concentrations of sulfate greater than $250 \mathrm{mg} / \mathrm{L}$ and dissolved iron greater than $7 \mathrm{mg} / \mathrm{L}$; approximately half of these samples also had concentrations of dissolved manganese greater than $5 \mathrm{mg} / \mathrm{L}$ and dissolved aluminum greater than $1 \mathrm{mg} / \mathrm{L}$ (Cravotta 2007). These levels of dissolved metals exceed criteria for effluent from active mines in Pennsylvania (Commonwealth of Pennsylvania 2002). Various strategies for treatment to remove the dissolved iron and associated metals from AMD before it discharges to streams could be appropriate depending on the volume of the mine discharge, its alkalinity and acidity balance, and the available resources for construction and maintenance of a treatment system (Hedin et al. 1994; Skousen et al. 1998; PIRAMID Consortium 2003; Watzlaf et al. 2004). Published AMD passive-treatment guidelines can be inadequate in determining an optimum treatment strategy for a specific AMD source, and few data are typically available to evaluate the effectiveness or long-term maintenance requirements of existing passivetreatment systems.

\section{Background}

Acidity and metals can be removed from AMD through the use of passive-treatment systems that increase $\mathrm{pH}$ and alkalinity, promote the oxidation of dissolved ferrous $\left(\mathrm{Fe}^{\mathrm{II}}\right.$ ) and manganous $\left(\mathrm{Mn}^{\mathrm{II}}\right)$ species, and ultimately facilitate settling of suspended metal-rich particles (Hedin et al. 1994; Skousen et al. 1998; PIRAMID Consortium 2003; Watzlaf et al. 2004). Various passive-treatment systems incorporate crushed limestone that is flooded continuously with AMD to neutralize the acidity, thereby generating alkalinity. The dissolution of calcite $\left(\mathrm{CaCO}_{3}\right)$ and dolomite $\left(\mathrm{CaMg}\left(\mathrm{CO}_{3}\right)_{2}\right)$, which are the principal minerals in limestone, increases the $\mathrm{pH}$, alkalinity $\left(\mathrm{HCO}_{3}{ }^{-}+\mathrm{CO}_{3}{ }^{2-}+\right.$ $\mathrm{OH}^{-}$), and concentrations of calcium (Ca) and magnesium $(\mathrm{Mg})$ in a contacting solution by the following overall reactions:

$$
\begin{aligned}
& \mathrm{CaCO}_{3}(\mathrm{~s})+\mathrm{H}^{+} \leftrightarrow \mathrm{Ca}^{2+}+\mathrm{HCO}_{3}^{-} \\
& \left.\mathrm{CaMg} \mathrm{CO}_{3}\right)_{2}(\mathrm{~s})+2 \mathrm{H}^{+} \leftrightarrow \mathrm{Ca}^{2+}+\mathrm{Mg}^{2+}+2 \mathrm{HCO}_{3}^{-} \\
& \mathrm{HCO}_{3}^{-}+\mathrm{H}^{+} \leftrightarrow \mathrm{H}_{2} \mathrm{CO}_{3}^{*} \leftrightarrow \mathrm{H}_{2} \mathrm{O}+\mathrm{CO}_{2}(\mathrm{~g})
\end{aligned}
$$

The $\mathrm{HCO}_{3}{ }^{-}$produced by Eqs. 1 and 2 can neutralize additional acid $\left(\mathrm{H}^{+}\right)$by Eq. 3. Although the above reactions indicate that $\mathrm{CaCO}_{3}$ and $\mathrm{CaMg}\left(\mathrm{CO}_{3}\right)_{2}$ have comparable neutralization potential per mmol $\mathrm{Ca}^{2+}$ or $\mathrm{Mg}^{2+}$, the dissolution rate of dolomite tends to be slower than that for calcite under the same environmental conditions (Cravotta et al. 2008; Herman and White 1985). Hence, high-purity calcitic limestone generally is specified for use in passive-treatment systems (e.g. Hedin et al. 1994).
For example, an "anoxic limestone drain" (ALD) consists of crushed limestone of uniform size that is placed in a buried bed to intercept net-acidic AMD before its exposure to atmospheric oxygen $\left(\mathrm{O}_{2}\right)$ (Brodie et al. 1991; Cravotta 2003; Hedin and Watzlaf 1994 Turner and McCoy 1990). Excluding $\mathrm{O}_{2}$ from contact with the water in an ALD minimizes the potential for oxidation of $\mathrm{Fe}^{\mathrm{II}}$ to $\mathrm{Fe}^{\mathrm{III}}$ and the consequent precipitation of $\mathrm{Fe}(\mathrm{OH})_{3}$ and related solids (e.g. Bigham and Nordstrom 2000; Hammarstrom et al. 2003). As the pH increases to near-neutral values in an ALD, concentrations of dissolved $\mathrm{Fe}^{\mathrm{III}}$, $\mathrm{Al}$, and other metals in AMD tend to decrease owing to their precipitation or adsorption; however, concentrations of $\mathrm{SO}_{4}, \mathrm{Fe}^{\mathrm{II}}$, and $\mathrm{Mn}^{\mathrm{II}}$ generally will not be affected (Cravotta 2003; Cravotta and Trahan 1999). After routing the AMD through the ALD, the partially treated effluent typically is diverted through ponds and/or wetlands where exposure to the atmosphere promotes $\mathrm{Fe}^{\mathrm{II}}$ oxidation and the precipitation and settling of solid $\mathrm{Fe}(\mathrm{OH})_{3}$ (Hedin et al. 1994; Kirby et al. 1999; Skousen et al. 1998; Watzlaf et al. 2004).

The precipitation of $\mathrm{Fe}(\mathrm{OH})_{3}, \mathrm{Al}(\mathrm{OH})_{3}$, gypsum, and various other secondary compounds within a limestonebased treatment system can "armor" the limestone surfaces, potentially decreasing the rate and extent of limestone dissolution and alkalinity production (Hedin and Watzlaf 1994; Robbins et al. 1999; Cravotta and Trahan 1999; Hammarstrom et al. 2003). Furthermore, the accumulation of precipitated compounds can decrease the porosity and permeability of the limestone bed (Cravotta and Watzlaf 2002; Robbins et al. 1996; Watzlaf et al. 2000; Weaver et al. 2004). Hence, design criteria for ALDs as originally proposed by Hedin and Watzlaf (1994) and Hedin et al. (1994) and widely adopted at present (e.g. PIRAMID Consortium 2003; Watzlaf et al. 2004) generally are conservative with respect to the permissible concentrations of dissolved $\mathrm{O}_{2}, \mathrm{Fe}^{\mathrm{III}}$, and $\mathrm{Al}$ in influent $(<1 \mathrm{mg} / \mathrm{L}$ $\mathrm{O}_{2}, \mathrm{Fe}^{\mathrm{III}}$, or $\mathrm{Al}$ ) to minimize potential for clogging or armoring by $\mathrm{Fe}^{\mathrm{III}}$ or $\mathrm{Al}$ solids.

Stringent requirements for low concentrations of $\mathrm{O}_{2}$, $\mathrm{Fe}^{\mathrm{III}}$, and $\mathrm{Al}$ in the influent AMD make ALDs inappropriate for treatment of oxic or highly mineralized water, which commonly occurs in mined areas. For example, of 140 AMD samples from bituminous and anthracite coal mines in Pennsylvania (Cravotta 2007; Kirby and Cravotta $2005 \mathrm{~b}$ ), only $17 \%$ were net acidic and had $<1 \mathrm{mg} / \mathrm{L}$ of dissolved $\mathrm{O}_{2}, \mathrm{Fe}^{\mathrm{III}}$, and Al. Alternative treatments, including a "reducing and alkalinity producing system" (RAPS) or an "oxic limestone drain" (OLD), can be used for the neutralization and removal of metals from acidic effluent that does not meet criteria for an ALD.

In a RAPS, pretreatment through an organic-rich compost bed or the mixing of compost with the limestone 
is used to decrease concentrations of dissolved $\mathrm{O}_{2}, \mathrm{Fe}^{\mathrm{III}}$, and $\mathrm{Al}$ in the mine water to acceptable levels and minimize the precipitation of $\mathrm{Fe}(\mathrm{OH})_{3}, \mathrm{Al}(\mathrm{OH})_{3}$, and associated solids (Amos and Younger 2003; Demchak et al. 2001; Kepler and McCleary 1994; PIRAMID Consortium 2003; Rose 2004; Skousen et al. 1998; Watzlaf et al. 2000). The bacterial oxidation of organic matter (" $\mathrm{CH}_{2} \mathrm{O}$ ") in compost can decrease concentrations of dissolved $\mathrm{O}_{2}$ :

$\mathrm{CH}_{2} \mathrm{O}+\mathrm{O}_{2} \rightarrow \mathrm{H}_{2} \mathrm{O}+\mathrm{CO}_{2}(\mathrm{~g})$

In the absence of $\mathrm{O}_{2}$, the oxidation of organic matter may be coupled with the dissimilatory reduction of $\mathrm{Fe}^{\mathrm{III}}$ and sulfate (Appelo and Postma 1993; Drever 1997; Jones et al. 2006; Lovley 1991; Lovley and Phillips 1986; Todorova et al. 2005):

$\mathrm{CH}_{2} \mathrm{O}+4 \mathrm{Fe}(\mathrm{OH})_{3}+8 \mathrm{H}^{+} \rightarrow 4 \mathrm{Fe}^{2+}+11 \mathrm{H}_{2} \mathrm{O}+\mathrm{CO}_{2}(\mathrm{~g})$

$2 \mathrm{CH}_{2} \mathrm{O}+\mathrm{SO}_{4}^{2-} \rightarrow \mathrm{HS}^{-}+\mathrm{HCO}_{3}^{-}+\mathrm{CO}_{2}+\mathrm{H}_{2} \mathrm{O}$

By preventing the oxidation of $\mathrm{Fe}^{\mathrm{II}}$ and/or promoting the reduction of $\mathrm{Fe}^{\mathrm{III}}$ within the compost layer, clogging and armoring of underlying or commingled limestone fragments by $\mathrm{Fe}^{\mathrm{III}}$ oxides may be avoided. Also, the $\mathrm{CO}_{2}$ generated by the oxidation of compost (Eqs. 4-6) can promote limestone dissolution and alkalinity production, and the reductive dissolution of $\mathrm{Fe}^{\mathrm{III}}$ oxides (Eq. 5) or dissolved sulfate (Eq. 6) can increase $\mathrm{pH}$ and alkalinity, directly. Nevertheless, the reactivity of the compost in a RAPS can be short lived and/ or the compost can have a limiting transmissivity (Demchak et al. 2001). Furthermore, short-term laboratory studies ( $<2$ years) indicate that limestone alone can be as effective as compost plus limestone for neutralization of mine water containing dissolved $\mathrm{O}_{2}$ and low to moderate concentrations of $\mathrm{Fe}^{\mathrm{III}}$ and $\mathrm{Al}(<10 \mathrm{mg} / \mathrm{L})$ (Sterner et al. 1998; Watzlaf 1997).

In an OLD, compost is not used for treatment of effluent containing low to moderate concentrations of $\mathrm{Fe}^{\mathrm{III}}$ and $\mathrm{Al}(<5 \mathrm{mg} / \mathrm{L}) ; \mathrm{Fe}$ oxidation and hydrolysis reactions will not be prevented within the limestone bed but must be managed (Cravotta and Trahan 1999; Cravotta and Watzlaf 2002). If sufficiently rapid flow rates can be attained with periodic flushing, fresh precipitates can be transported as suspended particles through the limestone bed. Perforated piping can be installed within or beneath the limestone bed of RAPS and OLD systems to facilitate the flushing of accumulated precipitates. Although some studies have reported on systems designed for the efficient flushing of metal-rich solids from limestone beds (Schueck et al. 2004; Weaver et al. 2004), consensus on design criteria for flushable passive-treatment systems has not been reached.
Purpose and Scope

This paper describes field water-quality data collected by the U.S. Geological Survey (USGS) for the evaluation of passive-treatment strategies and performance results at a netacidic, flooded underground anthracite mine in eastern Pennsylvania. Treatment-system performance is demonstrated with data on $\mathrm{pH}$, alkalinity, acidity, and other waterquality constituents collected monthly during March 2002 to December 2003 (before the treatment system began operation) and during March 2004 to March 2005 and October 2005 (after the treatment system began operation) at the inflow, outflow, and intermediate points within the treatment system and on the receiving stream above and below the discharge. Potential environmental benefits of treatment are indicated by aquatic biological surveys conducted annually in 2002 through 2005 on the stream above and below the discharge. A companion paper (Cravotta et al. 2008) describes laboratory neutralization-rate experiments with the untreated AMD and uncoated dolomitic limestone, uncoated calcitic limestone, and $\mathrm{Fe}(\mathrm{OH})_{3}$-coated calcitic limestone.

\section{Description of Study Area}

The Bell Mine Water-Level Tunnel (lat. $40^{\circ} 45^{\prime} 10^{\prime \prime} \mathrm{N}$, long. $76^{\circ} 02^{\prime} 53^{\prime \prime} \mathrm{W}$ ), hereinafter referred to as the Bell Discharge, discharges acidic, iron-laden ground water from an abandoned underground anthracite mine at the town of Mary D, Schuylkill County, and is the largest source of AMD near the headwaters of the Schuylkill River in eastern Pennsylvania (Growitz et al. 1985; L. Robert Kimball and Associates 2000; Pennsylvania Dept of Environmental Protection 2003; Williams et al. 2002; Wood 1996). The Schuylkill River Basin originates within the Southern Anthracite Coalfield of the Appalachian Mountain Section of the Ridge and Valley Physiographic Province where it is underlain by strongly folded and faulted sandstone, shale, siltstone, conglomerate, and anthracite of the Llewellyn and Pottsville Formations (Berg et al. 1980; Eggleston et al. 1999; Way 1999; Wood et al. 1986). Although several surface and underground anthracite mines presently (2007) are active, most underground mines in the upper Schuylkill River Basin were abandoned before 1960 and are flooded. Freshwater that enters the mines acquires acidity, sulfate, iron, and other metals and eventually discharges as AMD from mine shafts, tunnels, and other topographically low points. The metal-laden AMD contributes substantially to base flow and degrades stream-water quality and aquatic habitat of the Schuylkill River and its upper tributaries (Pennsylvania Dept of Environmental Protection 2003). Consequently, the upper Schuylkill River is on the U.S. Environmental Protection Agency (USEPA) 303(d) list of 
impaired waters in Pennsylvania (Pennsylvania Department of Environmental Protection 2004).

Data collected by the USGS from 1997 to 2005 for the Bell Discharge (U.S. Geological Survey 2007, site \# 404512076025501), indicate the AMD source has a wide range in flow $(16-133 \mathrm{~L} / \mathrm{s}$; median $43 \mathrm{~L} / \mathrm{s})$ and concentration of dissolved oxygen $(\mathrm{DO}=0.8-9.9 \mathrm{mg} / \mathrm{L})$, but is consistently net acidic $(\mathrm{pH}=3.6-4.9$; net acidity $=13-$ $35 \mathrm{mg} / \mathrm{L} \mathrm{CaCO}_{3}$ ), with elevated concentrations of sulfate $\left(\mathrm{SO}_{4}=81-190 \mathrm{mg} / \mathrm{L}\right)$, iron $(\mathrm{Fe}=1.3-15.0 \mathrm{mg} / \mathrm{L})$, manganese $(\mathrm{Mn}=1.0-2.2 \mathrm{mg} / \mathrm{L}), \quad$ aluminum $\quad(\mathrm{Al}=0.5-$ $1.9 \mathrm{mg} / \mathrm{L}$ ), and other dissolved metals compared to upstream water quality. On the basis of its flow characteristics and its net-acidic water quality, the effluent from Bell Discharge could be treated passively in a staged treatment system with limestone beds to neutralize acidity and wetlands for removal of iron and other metals (e.g. PIRAMID Consortium 2003; Skousen et al. 1998; Watzlaf et al. 2004).

It was hypothesized that a downflow system with limestone alone would be more effective for treatment of the oxic AMD of the Bell Discharge than a downflow system with compost over limestone. Under oxidizing conditions, a system constructed only of limestone would potentially increase the cost-effectiveness of treatment because of the rapid removal of $\mathrm{Fe}$ and $\mathrm{Al}$ under oxidizing conditions. However, the accumulation of metals also could cause clogging and armoring of the limestone bed. In contrast, a downflow system with compost over, or mixed with, limestone could decrease potential for $\mathrm{Fe}(\mathrm{OH})_{3}$ accumulation in the limestone bed but require longer detention time for the reoxidation and precipitation of $\mathrm{Fe}$ in the aerobic wetland.

\section{Materials and Methods}

\section{Treatment System Design and Construction}

A two-stage treatment system consisting of two, parallel downflow cells filled with limestone followed by an aerobic settling pond and wetland was constructed by the Schuylkill Conservation District at the Bell Discharge in fall and winter of 2003 (Fig. 1). To maintain transmissivity and to facilitate flushing of $\mathrm{Fe}(\mathrm{OH})_{3}$ and $\mathrm{Al}(\mathrm{OH})_{3}$ precipitate, large fragments of limestone aggregate equivalent to rip-rap size "R-4" (8-30 cm) or "R-5" (13-45 cm) (Pennsylvania Dept of Environmental Protection 2000) were used to construct the 2-m thick limestone beds. The treatment bed in cell A consisted solely of limestone to sustain the oxic inflow conditions. In cell B, a $0.3-\mathrm{m}$ thick layer of mushroom compost (e.g. Demchak et al. 2001; Kepler and McCleary 1994; Rose 2004; Skousen et al. 1998; Watzlaf et al. 2000) was placed on a geotextile filter over the limestone bed. Each of the two cells treated approximately half of the influent to the treatment system. Two separate underdrain networks and outflow pipes beneath cells A and B were installed (1) to enable flushing of accumulated metal-rich solids from the downflow cells to the wetland cell where final oxidation, precipitation, and settling of particles would occur; and (2) to allow for comparison of the effectiveness of the different downflow treatment designs. The combined flows from the two limestone cells were collected into an aerobic settling pond and wetland equipped with a rectangular weir at the outlet, near the original confluence of the discharge and the Schuylkill River.

The "as-built" system incorporated most basic features of the conceptual design. However, instead of using highpurity calcitic limestone with a minimum $\mathrm{CaCO}_{3}$ content of $85 \mathrm{wt} \%$ as specified in the design, a total of 1,090 metric tons (t) of dolomitic limestone with an average $\mathrm{CaCO}_{3}$ content of approximately $60 \mathrm{wt} \%$ was used to construct the treatment bed in each of cells A and B (Fig. 1). Preliminary testing, described by Cravotta et al. (2008), indicated that the dolomitic limestone could provide some neutralization, but not as efficiently as the high-purity calcitic limestone. Thus, an additional $300 \mathrm{t}$ of high-purity limestone with a minimum $\mathrm{CaCO}_{3}$ content of $95 \mathrm{wt} \%$ was added above the dolomitic layer in each cell. With the added high-purity calcitic limestone, the total mass of $\mathrm{CaCO}_{3}$ in each of the as-built treatment cells $\left(939 \mathrm{t} \mathrm{CaCO}_{3}=1,090 \mathrm{t} \cdot 0.60\right.$ $\left.\mathrm{CaCO}_{3} / \mathrm{t}+300 \mathrm{t} \cdot 0.95 \mathrm{CaCO}_{3} / \mathrm{t}\right)$ would be approximately equal to that originally specified $\left(927 \mathrm{t} \mathrm{CaCO}_{3}=1,090\right.$ $\left.\mathrm{t} \cdot 0.85 \mathrm{CaCO}_{3} / \mathrm{t}\right)$. Nevertheless, the dissolution rate of dolomite could be slower than the calcite and, hence, neutralization less effective than a system constructed entirely of high-purity calcitic limestone.

The extent of neutralization within each treatment cell was expected to increase with increased detention time, corresponding with decreased flow rate, as reported for previous studies (e.g. Cravotta and Trahan 1999; Cravotta and Watzlaf 2002). To estimate the detention time $\left(t_{\mathrm{d}}\right)$ within the limestone beds for each treatment cell, the estimated void volume $\left(V_{\mathrm{V}}\right)$ was divided by the flow rate $(Q)$ :

$t_{\mathrm{d}}=V_{\mathrm{V}} / Q$.

The void volume was estimated as the difference between the bulk volume $\left(V_{\mathrm{B}}\right)$ based on the cell dimensions and the stone volume $\left(V_{\mathrm{S}}\right)$ computed from the mass of stone $(M)$ divided by the stone density $\left(\rho_{\mathrm{S}}\right)$ :

$V_{\mathrm{V}}=V_{\mathrm{B}}-\left(M / \rho_{\mathrm{S}}\right)$.

From the mass of stone, bulk volume, and void volume, estimates were also computed for the porosity $(\phi)$ : $\phi=V_{\mathrm{V}} / V_{\mathrm{B}}$.

Given the above physical characteristics, the relations between flow rate, detention time, and reaction progress within the treatment system could be evaluated. 
Fig. 1 Illustrations of passive treatment system constructed in 2004 at the Bell Mine Discharge (lat. $40^{\circ} 45^{\prime} 10^{\prime \prime} \mathrm{N}$, long. $76^{\circ} 02^{\prime} 53^{\prime \prime} \mathrm{W}$ ): a Aerial photograph taken August 12, 2004 (used with permission from Rettew Associates Inc., 2004) and location map; b schematic section (not to scale) showing general flow directions within the treatment system. Cell A lacks compost, but has the other components in Cell B. Approximate water depth $(\mathrm{m})$, areas $\left(\mathrm{m}^{2}\right)$, volume capacity $\left(\mathrm{m}^{3}\right)$, and quantities of substrate (t) are shown below; $V_{B}$ indicates bulk volume, $V_{V}$ indicates void volume, $n a$ indicates not applicable

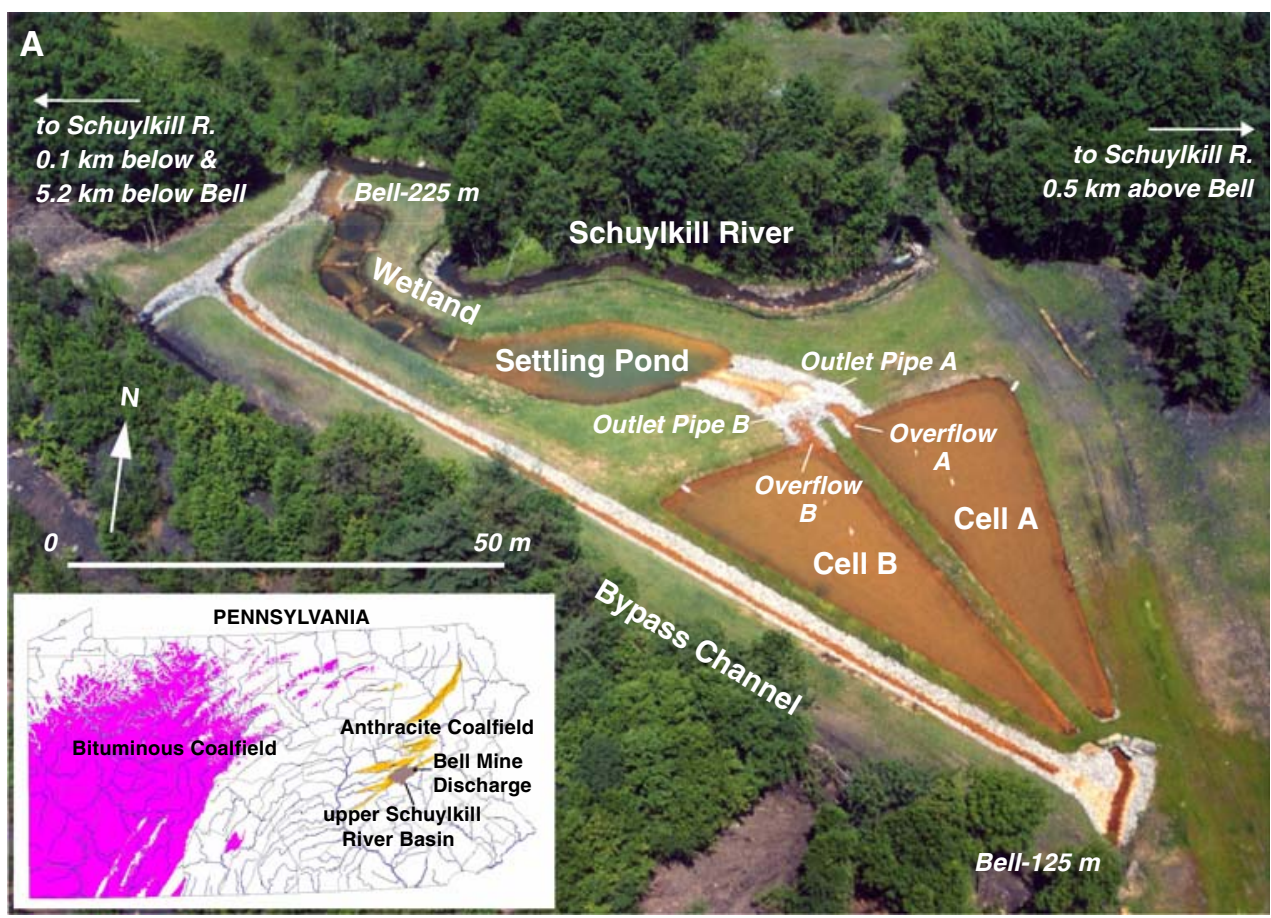

B

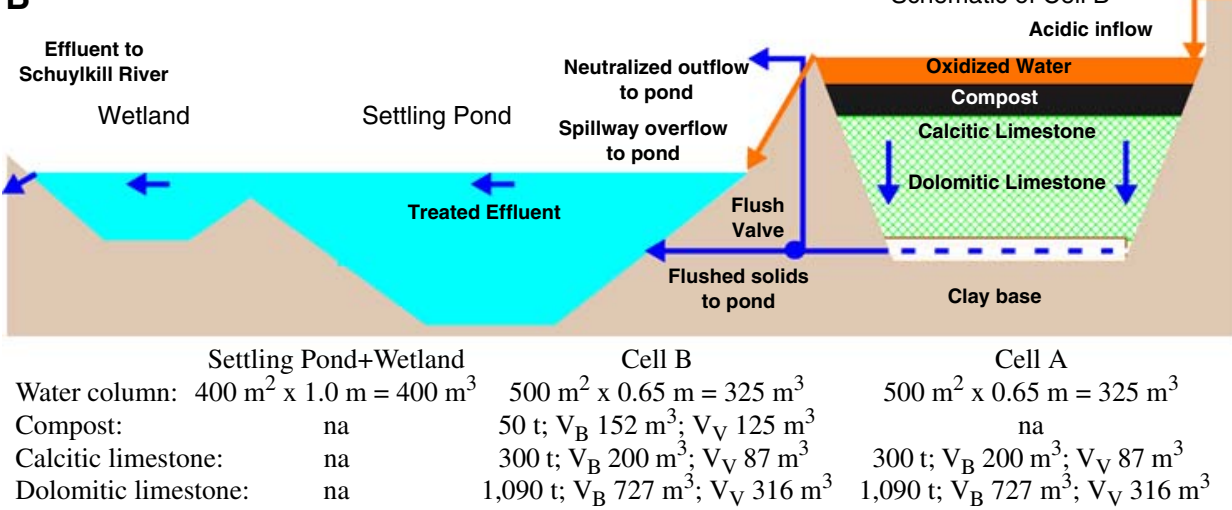

Water Quality Sampling and Analysis

During 2002-2005, data on the flow rates and water quality for the Bell Discharge, the treatment system, and the Schuylkill River above and below its confluence with the Bell Discharge were monitored to demonstrate the "measurable environmental results" of the treatment on the receiving stream, and the relative effectiveness of a downflow limestone system without compost, compared to one with compost, for treatment of oxic AMD. The monitoring data were collected by the USGS at fixed-time intervals over a range of hydrological conditions. Prior to construction of the treatment system, flow and waterquality data were collected monthly from March 2002 through December 2003 for the Schuylkill River above and below the confluence with the Bell Discharge plus on the Bell Discharge near its origin (Bell $125 \mathrm{~m}$; above the treatment system) and at the confluence with the Schuylkill River (Bell $225 \mathrm{~m}$; below the treatment system). After construction, data were collected monthly from April 2004 through March 2005 and in October 2005 at the original sites plus at the outflow pipes and overflows from cells A and $\mathrm{B}$ and the outflow from the aerobic wetland near the original confluence. Relative locations of monitoring sites are indicated in Fig. 1.

The flow rate of the Bell Discharge above the treatment system and the Schuylkill River $0.5 \mathrm{~km}$ above the Bell Discharge were measured by using a wading rod and pygmy current meter (Rantz et al. 1982a, b). The flow rate of the Schuylkill River $0.1 \mathrm{~km}$ below the Bell Discharge was computed as the sum of the flow in the river above the Bell Discharge and that of the discharge. The flow rate through each treatment cell was assumed to be half of the flow for the Bell Discharge. The flow rate through the pipe 
outlet from each treatment cell was measured using a bucket and stop watch, with flow over the spillway estimated as the difference between the total flow to the cell and the flow through the outlet pipe.

At each sample site, temperature, $\mathrm{pH}$, specific conductance (SC), DO, and redox potential (Eh) were measured by use of a multiparameter, submersible sonde. The sonde was calibrated daily when sampling in accordance with standard methods (U.S. Geological Survey 1997 to present). Field $\mathrm{pH}$ and Eh were determined by use of a combination $\mathrm{Pt}$ and $\mathrm{Ag} / \mathrm{AgCl}$ electrode with a $\mathrm{pH}$ sensor. The electrode was calibrated in $\mathrm{pH} 4.0$ and 7.0 buffer solutions and in ZoBell's solution (Wood 1976, pp. 18-22). Values for Eh were corrected to $25^{\circ} \mathrm{C}$ relative to the standard hydrogen electrode in accordance with methods of Nordstrom (1977). Unfiltered and filtered $(0.45-\mu \mathrm{m}$ pore size) samples of water were processed in the field, transferred to polyethylene bottles, preserved as appropriate, and transported on ice to the laboratory.

The alkalinity of the unfiltered water samples was titrated using sulfuric acid $\left(\mathrm{H}_{2} \mathrm{SO}_{4}\right)$ to a fixed endpoint $\mathrm{pH}$ of 4.5 (American Public Health Association 1998a). Typically, alkalinities were measured within $24 \mathrm{~h}$ of sampling at the USGS Water Science Center laboratory in New Cumberland, Pennsylvania. Concentrations of major anions $\left(\mathrm{SO}_{4}, \mathrm{Cl}\right)$ in filtered, unpreserved subsamples were analyzed by ion chromatography (IC), and concentrations of major cations $(\mathrm{Ca}, \mathrm{Mg}, \mathrm{Na}, \mathrm{K})$ and selected trace metals $(\mathrm{Fe}, \mathrm{Mn}, \mathrm{Al}, \mathrm{Ni}, \mathrm{Zn})$ in unfiltered and filtered, acidified subsamples were analyzed by inductively coupled plasma optical emission spectrometry (ICP) at the Actlabs laboratory in Toronto, Ontario, or the USGS Mineral Resources Laboratory (MRL) in Denver, Colorado (Crock et al. 1999; Fishman and Friedman 1989). The water-quality data were compiled as digital records in the National Water Information System (U.S. Geological Survey 2007).

Instead of measuring hot acidity, the net acidity was computed considering positive acidity contributions from protons $\left(\mathrm{H}^{+} ; \mathrm{pH}\right)$ and concentrations of dissolved iron, manganese, and aluminum $\left(\mathrm{C}_{\mathrm{Fe}}, \mathrm{C}_{\mathrm{Mn}}\right.$, and $\mathrm{C}_{\mathrm{Al}}$, respectively), in $\mathrm{mg} / \mathrm{L}$, and negative contributions from alkalinity as:

Net Acidity $\left(\mathrm{mg} / \mathrm{L} \mathrm{CaCO}_{3}\right)$

$$
\begin{aligned}
& =50,000\left(\begin{array}{c}
10^{(-\mathrm{pH})}+2 \mathrm{C}_{\mathrm{Fe}} / 55,850+2 \mathrm{C}_{\mathrm{Mn}} / 54,940 \\
+3 \mathrm{C}_{\mathrm{Al}} / 26,980
\end{array}\right) \\
& - \text { Alkalinity }\left(\mathrm{mg} / \mathrm{L} \mathrm{CaCO}_{3}\right) .
\end{aligned}
$$

Kirby and Cravotta (2005a, b) showed that net acidity computed with Eq. 10 is comparable in value to the standard hot acidity method, where the $\mathrm{H}_{2} \mathrm{SO}_{4}$ added to the sample is subtracted from the $\mathrm{NaOH}$ added (American Public Health Association 1998b). As explained by Kirby and Cravotta (2005a, b), no distinction is made for $\mathrm{Fe}^{\mathrm{II}}$ and $\mathrm{Fe}^{\mathrm{III}}$ in Eq. 10 because $\mathrm{Fe}^{\mathrm{III}}$-hydroxyl complexes at $\mathrm{pH}$ values greater than 3 reduce the capacity of $\mathrm{Fe}^{\mathrm{III}}$ to neutralize base.

The geochemical program WATEQ4F version 2.63 (Ball and Nordstrom 1991) was used to compute the $\mathrm{PcO}_{2}$, $\mathrm{Po}_{2}$, and saturation index (SI) values for selected minerals. The activities of $\mathrm{Fe}^{2+}$ and $\mathrm{Fe}^{3+}$ were computed on the basis of the measured concentration of dissolved iron, Eh, and temperature. The $\mathrm{Pco}_{2}$ was computed on the basis of measured $\mathrm{pH}$, alkalinity, and temperature.

In addition to chemical monitoring, annual aquatic ecological surveys were conducted in October 2002, 2003, and 2004 on the Schuylkill River at one site $0.5 \mathrm{~km}$ upstream and two sites 0.1 and $5.2 \mathrm{~km}$ downstream, respectively, from the confluence with the Bell Discharge. In October 2005, a final ecological survey was conducted at the two sites immediately upstream and downstream of the Bell Discharge. Fish were collected by electrofishing over a $100 \mathrm{~m}$ reach consisting of mixed riffle, run, and pool habitats at each stream site, held for measurement and identification, checked for anomalies, and then released in accordance with methods described by Meador et al. (1993) and Barbour et al. (1999).

\section{Results: Field Observations}

\section{Schuylkill River above and below Bell Discharge}

Contributions of flow and contaminants from the Bell Discharge to the Schuylkill River varied considerably during the study (Fig. 2). When water quality samples were collected during 2002 through 2005, the flow of the Schuylkill River above the Bell Discharge ranged from 4.25 to $228 \mathrm{~L} / \mathrm{s}$ and frequently was greater than that of the Bell Discharge by a factor of 2 or more (Fig. 2a). However, during low base-flow conditions in July through September of 2002 and July through August 2003, the flow of the Schuylkill River above the confluence ranged from 4.25 to $22.9 \mathrm{~L} / \mathrm{s}$ and was less than or equal to the flow of the Bell Discharge (Fig. 2a). Consequently, the greatest effects from the Bell Discharge on flow and quality of the Schuylkill River were associated with low base-flow conditions. Because the Bell Discharge at its confluence with the Schuylkill River (Bell 225-m) typically had DO concentrations that were comparable to those upstream for the Schuylkill River (Fig. 2b), this characteristic of the Schuylkill River generally was unaffected downstream of the discharge. However, the temperature and chemical composition downstream of the Bell Discharge were intermediate between those for upstream samples and the Bell Discharge (Fig. 2c-1). 
A OBell AMD $\quad$ Bell_225 $\mathrm{m} \quad \Delta$ Schuylkill_ab $\diamond$ Schuylkill_bl

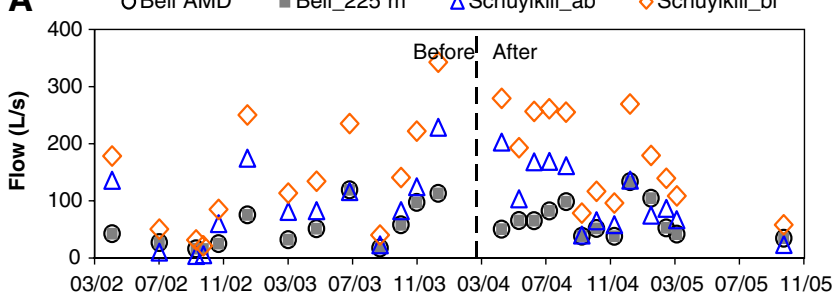

$\begin{array}{llllllllllllllll}03 / 02 & 07 / 02 & 11 / 02 & 03 / 03 & 07 / 03 & 11 / 03 & 03 / 04 & 07 / 04 & 11 / 04 & 03 / 05 & 07 / 05 & 11 / 05\end{array}$

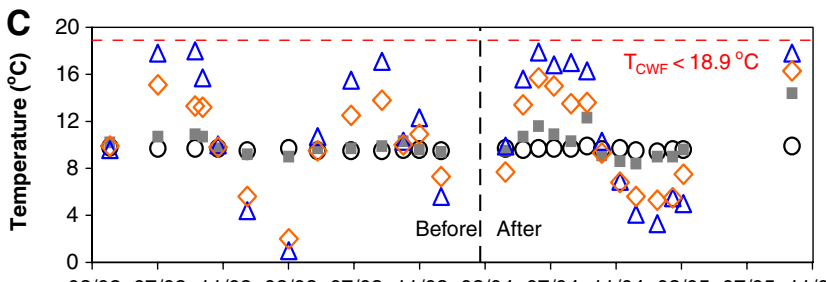

$\begin{array}{llllllllllllllllllllll}03 / 02 & 07 / 02 & 11 / 02 & 03 / 03 & 07 / 03 & 11 / 03 & 03 / 04 & 07 / 04 & 11 / 04 & 03 / 05 & 07 / 05 & 11 / 05\end{array}$
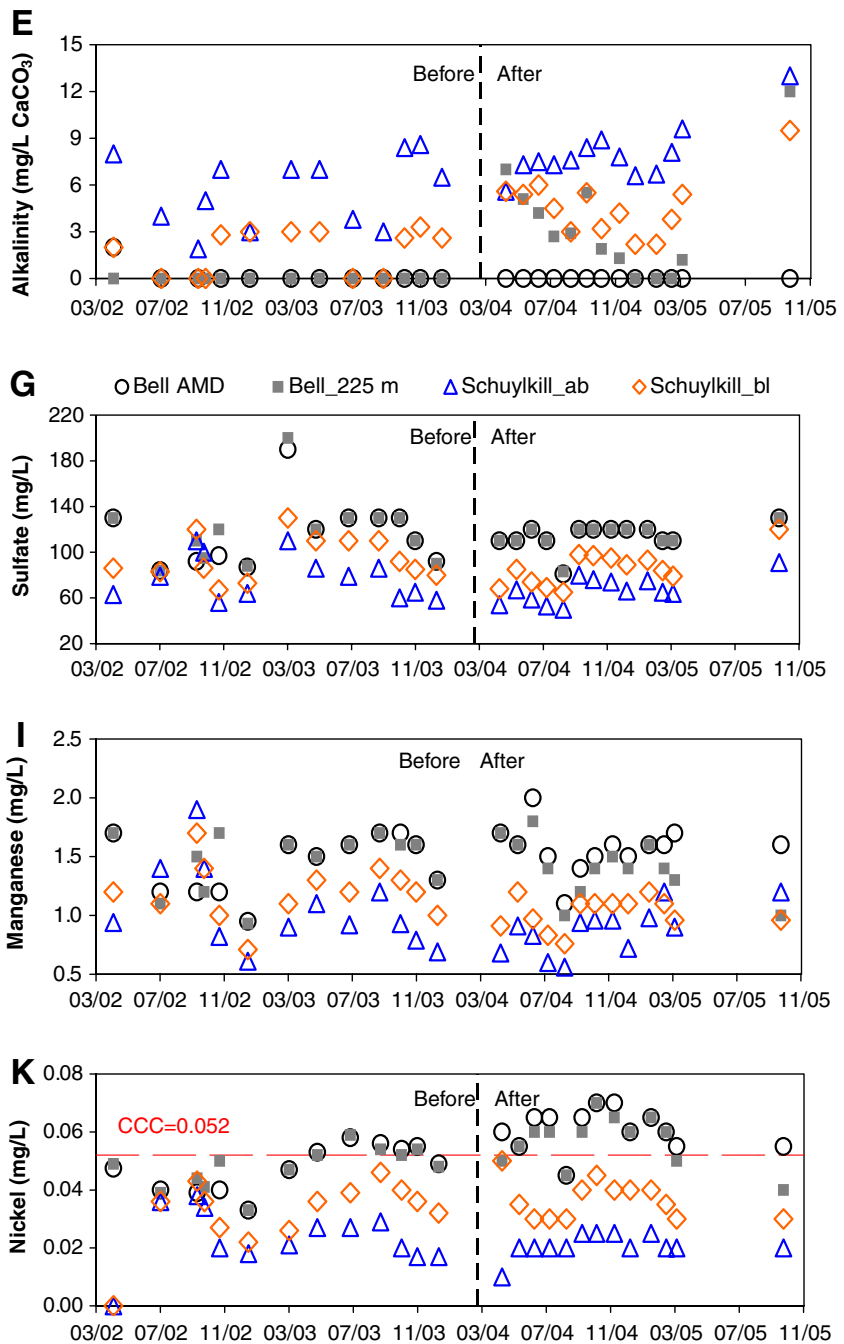

Fig. 2 Water quality at the Bell Mine (Bell AMD, Bell_225 m) and Schuylkill River above (Schuylkill_ab) and below (Schuylkill_bl) the Bell Discharge before (March 2002-February 2004) and after (March 2004-October 2005) treatment was initiated: a flow rate; b dissolved oxygen; c temperature; $\mathbf{d ~ p H}$; e alkalinity; f net acidity; $\mathbf{g}$ sulfate; h dissolved iron; i dissolved manganese; j dissolved aluminum;
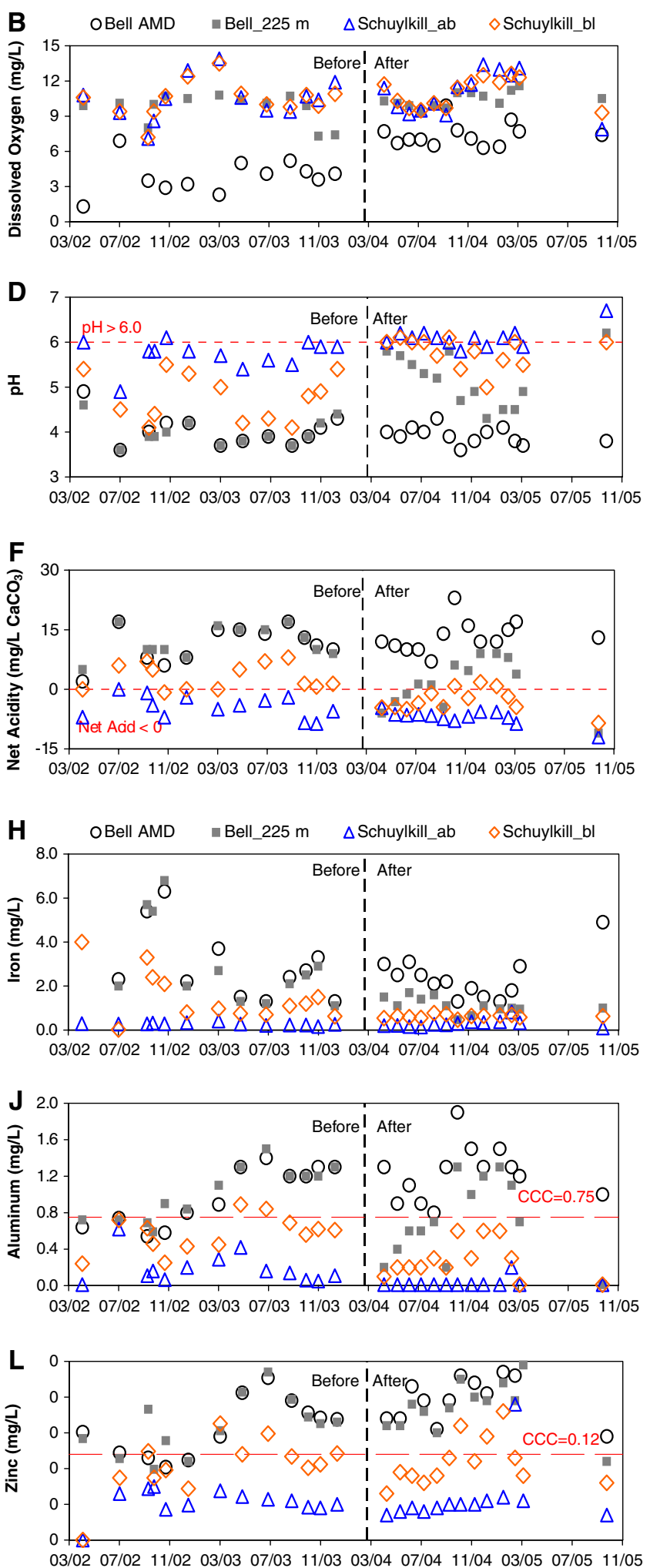

$\mathbf{k}$ dissolved nickel; $\mathbf{I}$ dissolved zinc. Values below detection plotted as negative (below axis). $T_{\mathrm{CWF}}$ is maximum temperature permitted for designated cold-water fisheries (Commonwealth of Pennsylvania 2002); CCC is criteria continuous concentration for freshwater organisms (U.S. Environmental Protection Agency 2002) 
The temperature of the Schuylkill River above and below the Bell Discharge varied seasonally, whereas the Bell Discharge had a nearly constant temperature equivalent to the annual average for the river (Fig. 2c). The Schuylkill River above the Bell Discharge had temperatures approaching $1^{\circ} \mathrm{C}$ in winter and $18^{\circ} \mathrm{C}$ in summer, whereas the temperature of Schuylkill River below the Bell Discharge ranged from 2 to $16^{\circ} \mathrm{C}$. Before the treatment system was installed, the Bell Discharge at its confluence with the Schuylkill River (Bell_225 m) ranged in temperature from 9.0 to $10.9^{\circ} \mathrm{C}$ (Fig. 2c); after the Bell Discharge was routed through the treatment system, the discharge temperature became more variable, decreasing to $8.4^{\circ} \mathrm{C}$ during winter and increasing to $14.4^{\circ} \mathrm{C}$ during summer. Nevertheless, because the temperature of the Bell Discharge remained relatively constant compared to the river, the temperature of the Schuylkill River below the Bell Discharge continued to be moderated with comparable temperature variability for the periods before and after the system began operations (Fig. 2c). The downstream water was maintained at less than the $18.9^{\circ} \mathrm{C}$ maximum temperature for cold-water fisheries in Pennsylvania (Commonwealth of Pennsylvania 2002).

Although the Schuylkill River above the Bell Discharge was relatively dilute and typically had near-neutral $\mathrm{pH}$, it was not pristine. Several upstream samples had $\mathrm{pH}$ less than 5.5 and net acidity greater than 0 , with concentrations of sulfate greater than $100 \mathrm{mg} / \mathrm{L}$ and manganese greater than $1.0 \mathrm{mg} / \mathrm{L}$ (Fig. 2), indicating probable effects from other AMD sources above the Bell Discharge. Nevertheless, the quality of water in the Schuylkill River below the Bell Discharge was further degraded because the Bell Discharge had consistently lower $\mathrm{pH}$ and greater concentrations of net acidity, sulfate, iron, aluminum, nickel, and zinc than those for the Schuylkill River above the discharge (Fig. 2d-1).

Degradation of the Schuylkill River below the Bell Discharge was indicated by decreased $\mathrm{pH}$ and increased concentrations of acidity and dissolved metals (Fig. 2). Downstream effects were pronounced during low baseflow conditions, characterized by $\mathrm{pH}$ as low as 4.1 before and 5.0 after the treatment system began operations (Fig. 2d). During the first year after the treatment system began operations, the concentration of dissolved iron in the river below the Bell Discharge was maintained less than $0.8 \mathrm{mg} / \mathrm{L}$ (Fig. 2h), and dissolved aluminum and nickel did not exceed the U.S. Environmental Protection Agency (2002) dissolved metal "criteria continuous concentration" (CCC) values of 0.75 and $0.052 \mathrm{mg} / \mathrm{L}$, respectively, for protection of freshwater aquatic organisms (Fig. 2j, k). Nevertheless, during the monitoring periods before and after treatment, concentrations of dissolved zinc in the Schuylkill River below the Bell Discharge occasionally exceeded the U.S. Environmental Protection Agency (2002) CCC value of $0.12 \mathrm{mg} / \mathrm{L}$ (Fig. 21).

Despite potentially toxic conditions associated with dissolved zinc and possible synergistic effects from various other contaminants, the annual fish surveys conducted in October 2002 through October 2005 indicated three different fish species-brook trout (Salvelinus fontinalis), brown bullhead (Ameiurus nebulosus), and pumpkinseed (Lepomis gibbosus)_inhabited the Schuylkill River in the vicinity of the Bell Discharge (Table 1). These fish species were characterized by Barbour et al. (1999) as tolerant to moderately tolerant of pollution and can be found in relatively low-pH waters draining uplands across Pennsylvania (Butler et al. 1973) (Table 1). Notably, within the first year of treatment, adult brook trout were documented immediately below the treatment system, but not in the reach above where the water temperature was warmer (Table 1). The trout probably migrated from downstream reaches; brook trout were the dominant fish species in the Schuylkill River at Middleport $5.2 \mathrm{~km}$ downstream of the Bell Discharge (Table 1). The fish survey was not conducted at Middleport in 2005 because previous surveys had documented numerous fish at this site and minor, if any, effects from upstream AMD sources. The Schuylkill River becomes progressively larger downstream from the Bell Discharge and, in addition to better water quality, offers deeper pools and better habitat than the upstream sites.

\section{Bell Discharge Treatment System}

The monthly water-quality data for the period after the treatment system began operations exhibited differences in flow and chemical concentrations among the untreated influent (Bell_AMD), treated effluent from the outlet pipes on cell A (CellA_Pipe) and cell B (CellB_Pipe), overflow from the spillways on cell A (CellA_Spillway) and cell B (CellB_Spillway), and the combined effluent from the aerobic settling pond and wetland (Bell_225 m) to the Schuylkill River (Fig. 3, Table 2). The inflow to the treatment system was split equally into cells A and B. To be treated effectively, the influent had to migrate downward through the treatment media. However, because of limited transmissivities of the treatment substrates within cells A and B, only a fraction of the influent percolated through the treatment beds to the associated discharge pipes; a substantial fraction flowed horizontally through the overlying water column and then over the spillways to each of cells A and B. For cell A, the median flow from the outlet pipe $(15.2 \mathrm{~L} / \mathrm{s})$ was comparable to the flow over the spillway $(13.7 \mathrm{~L} / \mathrm{s})$; for cell $\mathrm{B}$, the median flow from the outlet pipe $(4.81 \mathrm{~L} / \mathrm{s})$ was about $20 \%$ of that over the spillway (23.4 L/s) (Table 2). Consistently smaller flow 
Table 1 Fish species identified and number of individuals counted during annual ecological surveys of the Schuylkill River near Mary D, Pa., above and below the Bell Discharge, and near Middleport, Pa., 2002-2005

\begin{tabular}{|c|c|c|c|c|c|c|c|c|c|c|c|c|c|c|}
\hline \multicolumn{2}{|l|}{ Taxa } & \multirow{4}{*}{$\begin{array}{l}\text { Minimum } \\
\mathrm{pH} \text { in } \mathrm{PA}^{\mathrm{a}}\end{array}$} & \multirow{4}{*}{$\begin{array}{l}\text { Pollution } \\
\text { tolerance }^{\mathrm{b}}\end{array}$} & \multicolumn{11}{|c|}{ Number counted on Schuylkill River at Station } \\
\hline \multirow{3}{*}{$\begin{array}{l}\text { Order } \\
\text { Family } \\
\text { Genus species }\end{array}$} & \multirow[t]{3}{*}{ Common name } & & & \multirow{2}{*}{\multicolumn{4}{|c|}{$\begin{array}{l}0146742498 \\
\text { Above Bell } \\
40^{\circ} 45^{\prime} 16^{\prime \prime} \mathrm{N} \\
76^{\circ} 02^{\prime} 44^{\prime \prime} \mathrm{W}\end{array}$}} & \multirow{2}{*}{\multicolumn{4}{|c|}{$\begin{array}{l}0146742500 \\
\text { Below Bell } \\
40^{\circ} 45^{\prime} 12^{\prime \prime} \mathrm{N} \\
76^{\circ} 03^{\prime} 01^{\prime \prime} \mathrm{W}\end{array}$}} & \multirow{2}{*}{\multicolumn{3}{|c|}{$\begin{array}{l}01467448 \\
\text { Middleport } \\
40^{\circ} 43^{\prime} 43^{\prime \prime} \mathrm{N} \\
76^{\circ} 05^{\prime} 13^{\prime \prime} \mathrm{W}\end{array}$}} \\
\hline & & & & & & & & & & & & & & \\
\hline & & & & 02 & 03 & 04 & 05 & 02 & 03 & 04 & 05 & 02 & 03 & 04 \\
\hline \multicolumn{15}{|l|}{ Cypriniformes } \\
\hline \multicolumn{15}{|l|}{ Cyprinidae } \\
\hline Rhinichthys atratulus & Blacknose dace & 5.6 & $\mathrm{~T}$ & 0 & 0 & 0 & 0 & 0 & 0 & 0 & 0 & 7 & 1 & \\
\hline Semotilus atromaculatus & Creek chub & 5.2 & $\mathrm{~T}$ & 0 & 0 & 0 & 0 & 0 & 0 & 0 & 0 & 24 & 4 & 0 \\
\hline \multicolumn{15}{|l|}{ Catostomidae } \\
\hline Catostomus commersoni & White sucker & 4.6 & $\mathrm{~T}$ & 0 & 0 & 0 & 0 & 0 & 0 & 0 & 0 & 19 & 6 & 2 \\
\hline \multicolumn{15}{|l|}{ Siluriformes } \\
\hline \multicolumn{15}{|l|}{ Ictaluridae } \\
\hline Ameiurus nebulosus & Brown bullhead & 4.6 & $\mathrm{~T}$ & 1 & 0 & 1 & 0 & 2 & 0 & 0 & 0 & 0 & 0 & 0 \\
\hline \multicolumn{15}{|l|}{ Salmoniformes } \\
\hline \multicolumn{15}{|l|}{ Salmonidae } \\
\hline Salvelinus fontinalis & Brook trout & 5.0 & M & 0 & 0 & 0 & 0 & 0 & 0 & 1 & 9 & 23 & 14 & 11 \\
\hline \multicolumn{15}{|l|}{ Perciformes } \\
\hline \multicolumn{15}{|l|}{ Centrarchidae } \\
\hline Lepomis cyanellus & Green sunfish & 6.4 & $\mathrm{~T}$ & 0 & 0 & 0 & 0 & 0 & 0 & 0 & 0 & 4 & 0 & 0 \\
\hline Lepomis gibbosus & Pumpkinseed & 4.6 & M & 1 & 0 & 0 & 0 & 0 & 0 & 0 & 0 & 0 & 0 & 0 \\
\hline Lepomis macrochirus & Bluegill & 6.5 & M & 0 & 0 & 0 & 0 & 0 & 0 & 0 & 0 & 0 & 1 & 0 \\
\hline Total number of individuals collected & & & & 2 & 0 & 1 & 0 & 2 & 0 & 1 & 9 & 77 & 26 & 14 \\
\hline Total number of species identified & & & & 2 & 0 & 1 & 0 & 1 & 0 & 1 & 1 & 5 & 5 & 3 \\
\hline
\end{tabular}

Values in italics indicate surveys after treatment had been initiated in 2005; survey at Middleport was not conducted in 2005

${ }^{a}$ Minimum $\mathrm{pH}$ of occurrence in freshwater in Pennsylvania as reported by Butler et al. (1973)

b Pollution tolerance: $I$ intolerant, $M$ moderate, $T$ tolerant, adapted from Barbour et al. (1999)

from the outlet pipe of cell B than the spillway from cell B or the outlet pipe of cell A indicates impedance to downward flow through the compost layer and underlying geotextile support fabric in cell B. Cell A did not include a compost layer and associated geotextile and, consequently, was more transmissive and treated greater volumes of water than cell $\mathrm{B}$.

When the monthly samples were collected during April 2004 through March 2005 and in October 2005, flow rates through the treatment system ranged from 34.6 to $133 \mathrm{~L} / \mathrm{s}$ (Fig. 3a). Corresponding, cumulative detention times within the entire treatment system were inversely related to the flow rate and ranged from 14.5 to $3.8 \mathrm{~h}$ (Table 2). Because the flow to the treatment system was split between cells $\mathrm{A}$ and $\mathrm{B}$, with a greater fraction percolating through the treatment substrate in cell A $(4.81-19 \mathrm{~L} / \mathrm{s})$ than cell B $(2.55-12.6 \mathrm{~L} / \mathrm{s})$, the detention times within the limestone beds of cell A (21.9-5.6 h) were substantially less than those in cell B (41.3-8.3 h) (Table 2). Furthermore, because of its larger volume, estimated detention times within the dolomitic limestone bed were 3.6 times greater than those within the thinner, overlying limestone bed in each cell. Nevertheless, small increases in the concentration of magnesium compared to calcium and alkalinity in effluent from various monitoring points within the treatment system (Figs. 3c-3e) indicate that the dolomitic limestone in cells A and B was relatively unreactive and unimportant as a source of alkalinity compared to the calcitic limestone.

The chemical quality of the effluent at the spillways of cells A and B was similar to the influent because the spillway effluent was composed predominantly of untreated influent mixed with a smaller fraction of partially treated water that interacted with the upper limestone bed (Table 2, Fig. 3b-1). The respective median values for the untreated influent (Bell AMD) and the effluent from spillways of cells A and B during April 2004 to October 2005 were as follows: $\mathrm{pH}$ of 3.9, 4.0, and 4.0; net acidity of 20,17, and $17 \mathrm{mg} / \mathrm{L}$ $\mathrm{CaCO}_{3}$; dissolved calcium of 17,18 , and $18 \mathrm{mg} / \mathrm{L}$; dissolved magnesium of 14,14 , and $14 \mathrm{mg} / \mathrm{L}$; dissolved 

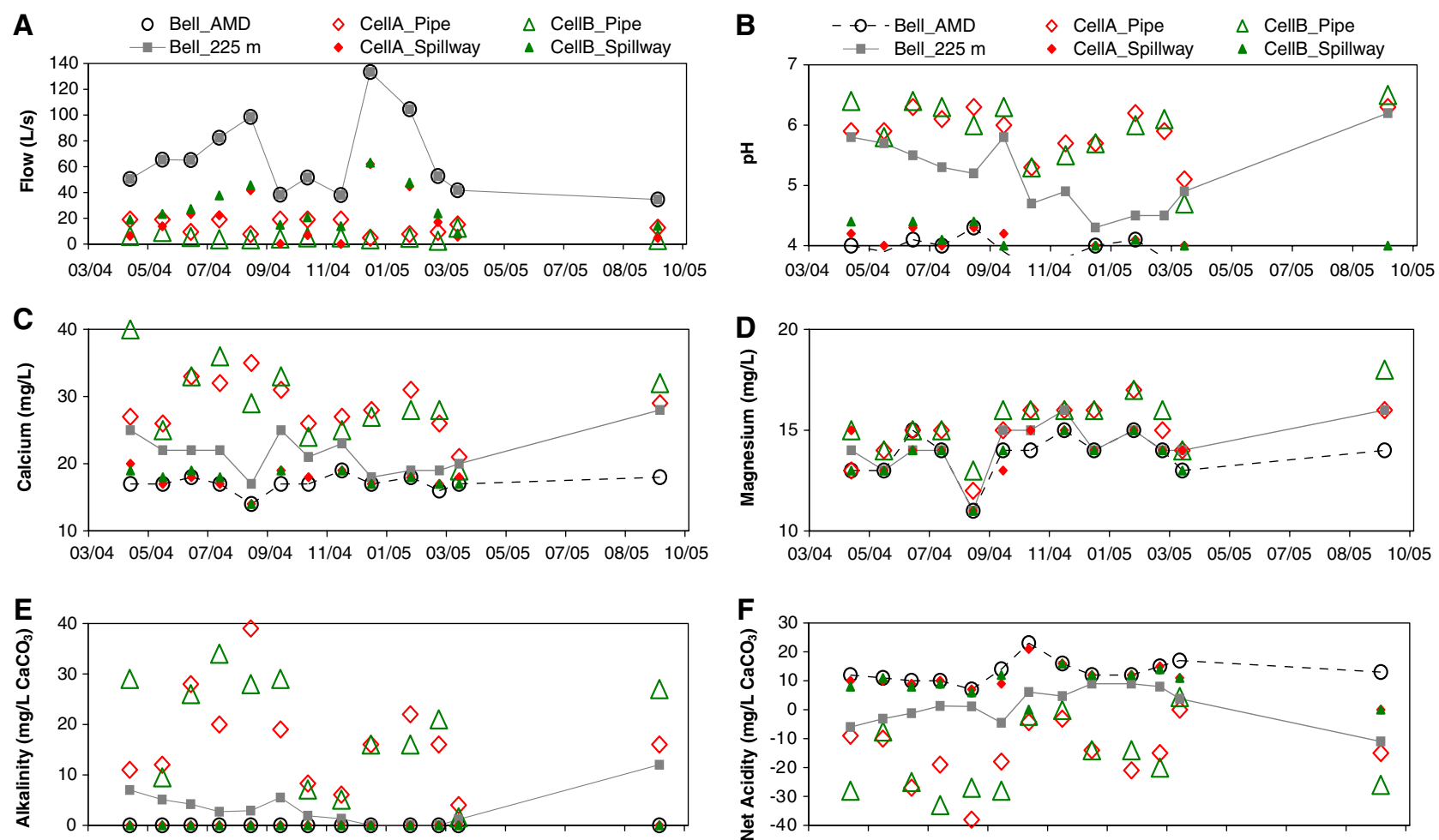

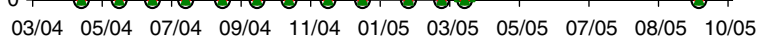
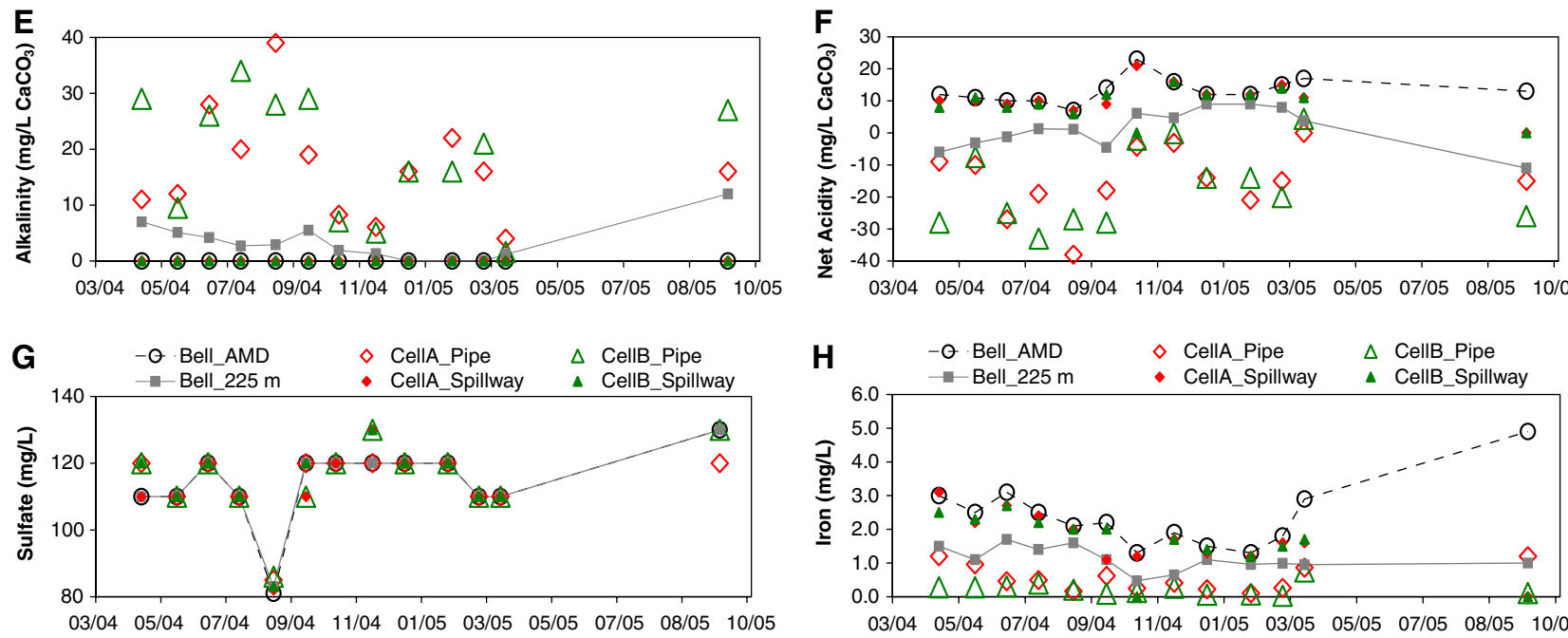

$\begin{array}{lllllllllll}03 / 04 & 05 / 04 & 07 / 04 & 09 / 04 & 11 / 04 & 01 / 05 & 03 / 05 & 05 / 05 & 07 / 05 & 08 / 05 & 10 / 05\end{array}$
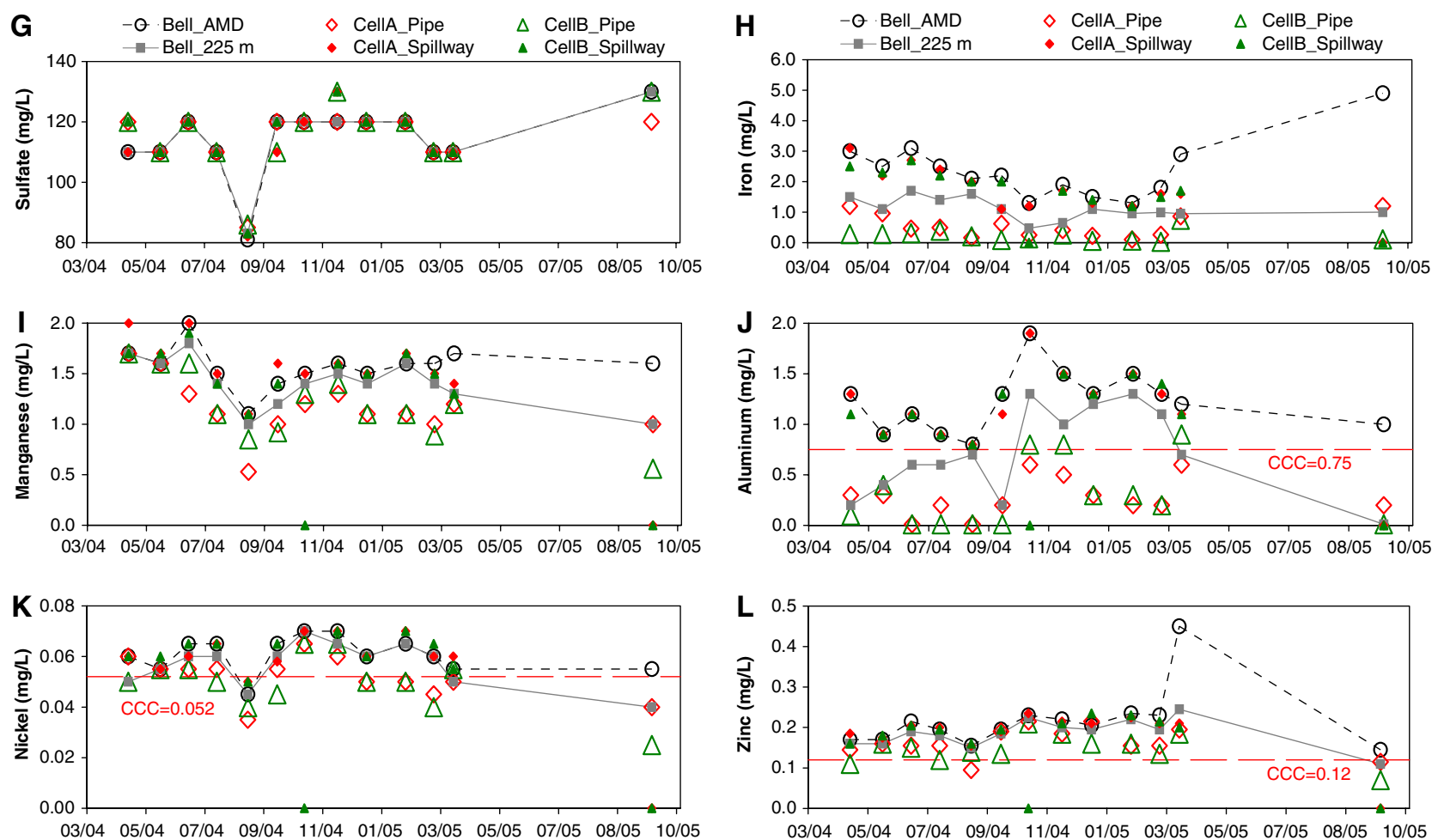

Fig. 3 Water quality within the Bell Discharge Treatment system (April 2004-October 2005): a flow rate; b pH; c calcium; d magnesium; e alkalinity; $\mathbf{f}$ net acidity; $\mathbf{g}$ sulfate; $\mathbf{h}$ dissolved iron; i dissolved manganese; $\mathbf{j}$ dissolved aluminum; $\mathbf{k}$ dissolved nickel; $\mathbf{l}$ dissolved zinc. Bell_AMD and Bell 225_m are influent and effluent of the treatment system; CellA_Pipe and CellB_pipe are the effluents from

underdrain pipes and CellA_Spillway and CellB_Spillway are the overflows from the respective downflow ponds. Values below detection limits were plotted as negative (below axis). CCC is criteria continuous concentration for freshwater organisms (U.S. Environmental Protection Agency 2002 ) 


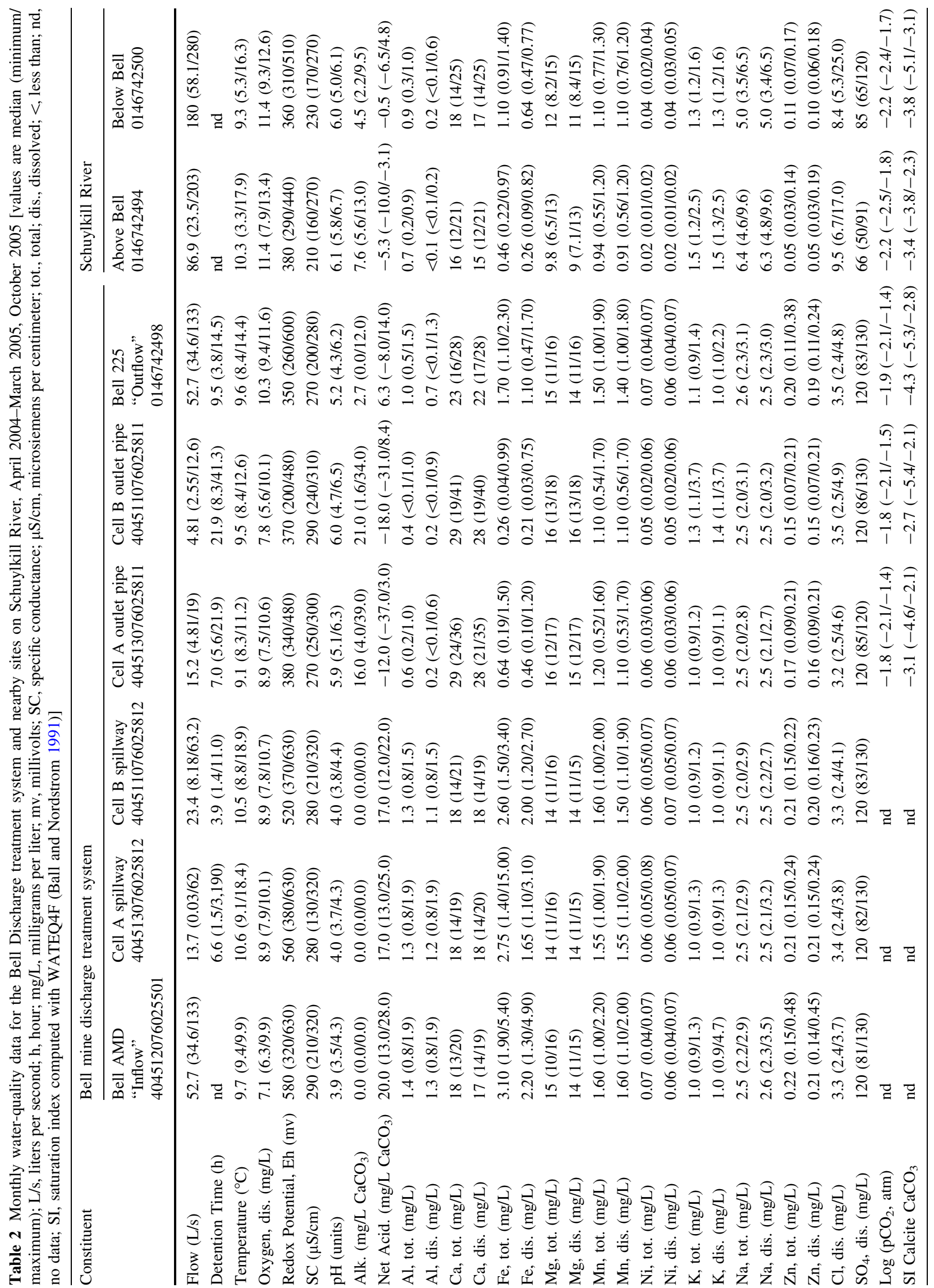




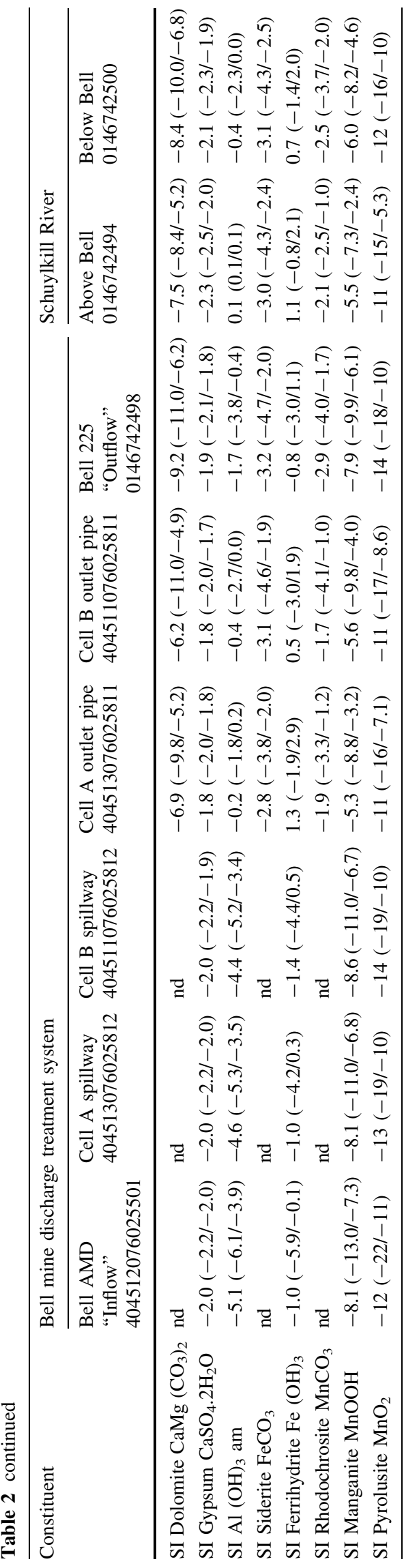

aluminum of $1.40,1.35$, and $1.30 \mathrm{mg} / \mathrm{L}$; dissolved iron of $2.20,1.65$, and $2.00 \mathrm{mg} / \mathrm{L}$; dissolved manganese of 1.60 , 1.55 , and $1.50 \mathrm{mg} / \mathrm{L}$; and dissolved sulfate of 120,120 , and $120 \mathrm{mg} / \mathrm{L}$ (Table 2).

In contrast, effluent from the outlet pipes draining the limestone beds of cells A and B had chemical characteristics that differed greatly from the influent, but only slightly from each other (Table 2, Figs. 3b-2l). The respective median values for the effluent from outlet pipes of cells A and B were as follows: $\mathrm{pH}$ of 5.9 and 6.0; net acidity of -12 and $-18 \mathrm{mg} / \mathrm{L} \mathrm{CaCO}_{3}$; dissolved calcium of 28 and $28 \mathrm{mg} / \mathrm{L}$; dissolved magnesium of 15 and $16 \mathrm{mg} / \mathrm{L}$; dissolved aluminum of 0.20 and $0.20 \mathrm{mg} / \mathrm{L}$; dissolved iron of 0.46 and $0.21 \mathrm{mg} / \mathrm{L}$; dissolved manganese of 1.10 and $1.10 \mathrm{mg} / \mathrm{L}$; and dissolved sulfate of 120 and $120 \mathrm{mg} / \mathrm{L}$ (Table 2). Despite the compost layer above the limestone in cell $\mathrm{B}$, the DO concentrations in effluent from the outlet pipe were comparable to those in the untreated influent and sampling points within cell A (Table 2). Furthermore, the decreased concentration of dissolved iron and constant concentration of sulfate at points through the treatment system indicate insignificant effects from dissimilatory reduction of $\mathrm{Fe}^{\mathrm{III}}$ (Eq. 7) or sulfate (Eq. 8) within the compost or other treatment media.

Most of the effluent sampled from cell B bypassed the compost layer because the geotextile filter fabric beneath the compost impeded downward flow through the compost to the underlying limestone. Thus, the anticipated chemical effects of the compost could not be evaluated on the basis of effluent from treatment cell B. Nevertheless, other studies have demonstrated the incorporation of organic rich compost within a limestone-based treatment system can enhance alkalinity production because of organic matter oxidation, sulfate reduction, $\mathrm{CO}_{2}$ production, and associated interaction with limestone (e.g. Amos and Younger 2003; Jage et al. 2001; Rose 2004; Thomas and Romanek 2002a, b; Watzlaf et al. 2000, 2004). The compost may be particularly effective for treatment of AMD with high concentrations of dissolved ferric iron and aluminum (Jage et al. 2001; Thomas and Romanek 2002b).

The magnitude of changes in $\mathrm{pH}$, alkalinity, calcium, and magnesium concentrations were inversely correlated with the flow rate through the limestone beds and the treatment system as a whole (Fig. 3). Generally, the differences between the influent and effluent values for $\mathrm{pH}$ and concentrations of dissolved constituents for the entire treatment system tended to be larger for low base-flow conditions when a large fraction of the influent flowed through the limestone beds. When the Bell Discharge flow rates increased, the flow rates through the limestone beds to the outlet pipes tended to increase; however, an increased fraction of the total inflow volume also flowed over the 
spillways of cells A and B (Fig. 3a). The increased values for $\mathrm{pH}$ and concentrations of alkalinity, calcium, and magnesium from the outlet pipes during low base-flow conditions and from cell B compared to cell A are consistent with more extensive neutralization reactions with increased detention time in the limestone bed(s). Nevertheless, considering loading rates of chemical constituents, greater detention times in cell B did not result in significantly improved treatment because smaller influent volumes were transmitted than through cell A (Figs. 4, 5).

On the basis of calcium, alkalinity, and net-acidity transport during April 2004 through October 2005, treatment with limestone only (cell A) was more effective than treatment with compost and limestone (cell B) (Figs. 4, 5). The positive transport values (mass added) for calcium and alkalinity and the negative transport values (mass removed) for acidity, iron, manganese, and aluminum for cell A exceeded those for cell B (Fig. 5). These findings are consistent with the results of Cravotta and Trahan (1999), who suggested that the release of protons from iron oxidation and hydrolysis in oxidizing limestone treatment systems can promote greater rates of limestone dissolution than comparable anoxic systems where neutralization and
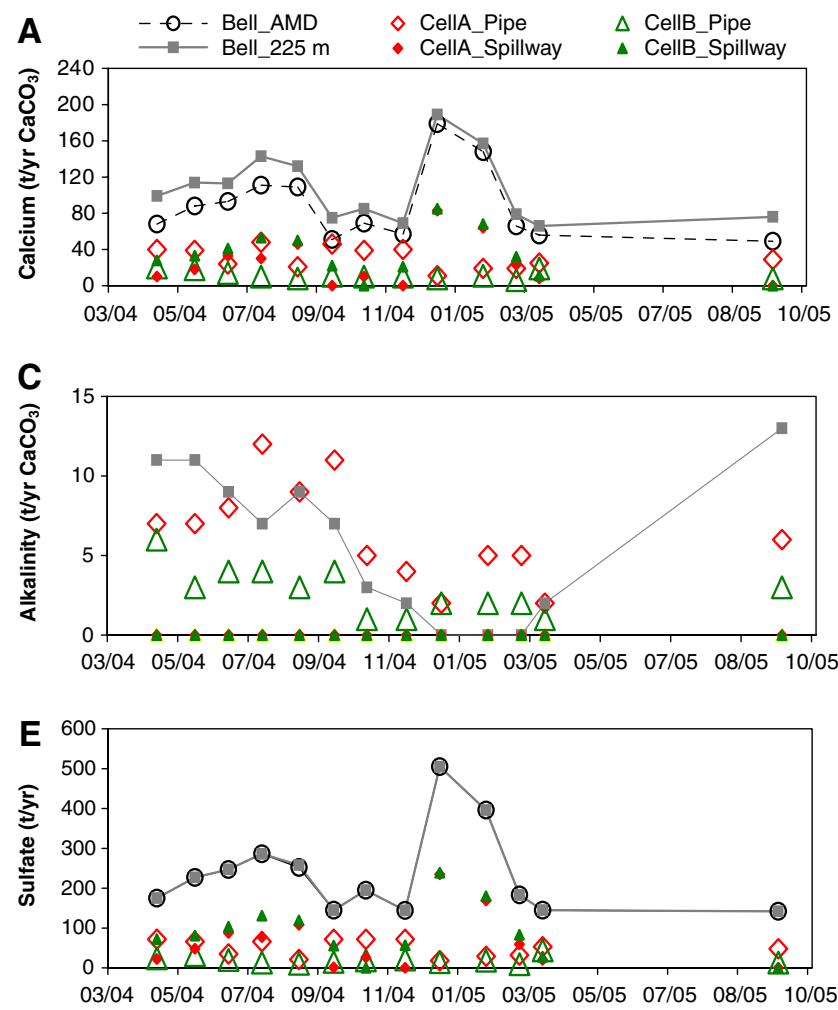

Fig. 4 Chemical loading, in metric tons per year ( $t / y)$, at monitoring points throughout the Bell Discharge Treatment system (April 2005October 2005): a calcium; b magnesium; c alkalinity; d net acidity; e sulfate; f sum of dissolved iron, manganese, and aluminum $(\mathrm{Fe}+\mathrm{Mn}+\mathrm{Al})$. Chemical loading computed as the product of flow oxidation reactions take place in separate, sequential steps. Also, as observed by Cravotta et al. (2004), the decreased loadings of alkalinity and calcium with decreased flow through a limestone bed (increased detention time) are consistent with nonlinear, asymptotic increases in concentration with increased detention time described by Cravotta et al. (2008) for the cubitainer tests of the rate of reaction between AMD and limestone.

Transport of calcium, magnesium, net acidity, sulfate, and dissolved metals (iron, manganese, and aluminum) to and from the treatment system during April 2004 through October 2005 (Figs. 4a-2f) was positively correlated with the influent flow rate (Fig. 3a). Sulfate was transported conservatively through the treatment system, with average influent and effluent loadings of 234 metric tons per year (t/y) (Figs. 3g, 4e, 5e). Although magnesium increased by only $1.9 \mathrm{t} / \mathrm{y}$ as $\mathrm{MgCO}_{3}$ (Figs. $4 \mathrm{~b}, 5 \mathrm{~b}$ ) or $1.9 \%$ per year, calcium was added at a rate of $19.6 \mathrm{t} / \mathrm{y}$ as $\mathrm{CaCO}_{3}$ (Figs. 4a, 5a) corresponding to an increase of $22.3 \%$ per year. Net acidity decreased by $24.8 \mathrm{t} / \mathrm{y}$ as $\mathrm{CaCO}_{3}$ consistent with an annual removal rate of $62 \%$ per year that resulted from increased $\mathrm{pH}$ and alkalinity and the removal of $3.2 \mathrm{t} / \mathrm{y}$ dissolved iron, manganese, and aluminum. On the whole,
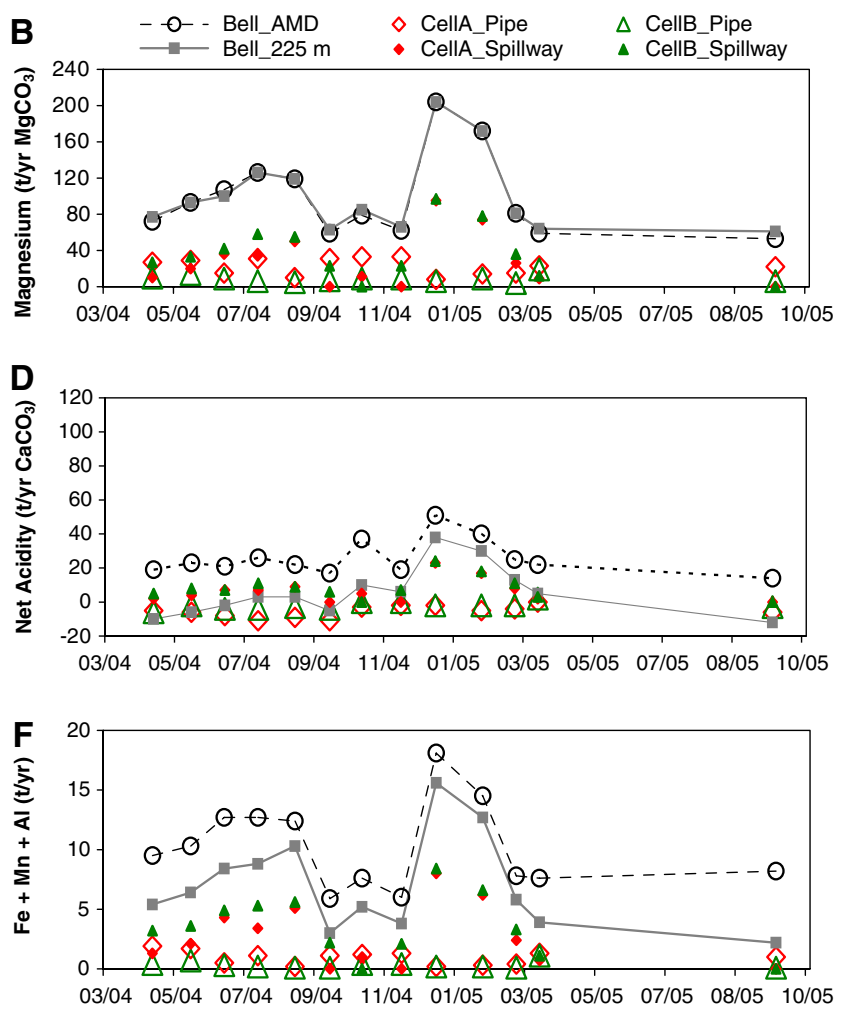

rate and concentration of constituent in effluent for each monitoring point. Bell_AMD and Bell 225_m are influent and effluent of the treatment system; CellA_Pipe and CellB_pipe are the effluents from the underdrain pipes and CellA_Spillway and CellB_Spillway are the overflows from the respective downflow ponds 

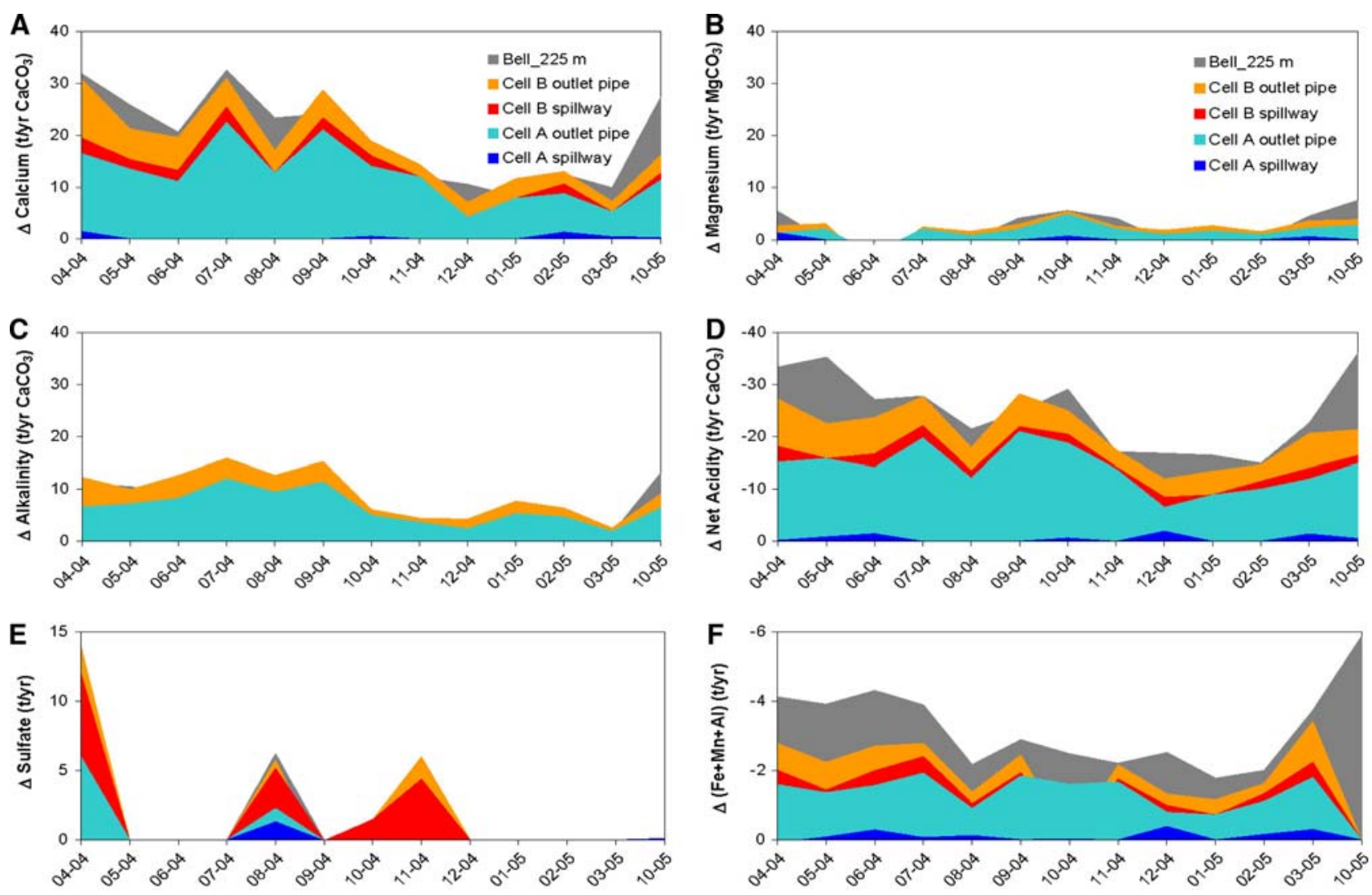

Fig. 5 Cumulative changes in chemical loading, in metric tons per year (t/y), at monitoring points throughout the Bell Discharge Treatment system (April 2005-October 2005): a calcium; b magnesium; c alkalinity; $\mathbf{d}$ net acidity; e sulfate; $\mathbf{f}$ sum of dissolved iron, manganese, and aluminum ( $\mathrm{Fe}+\mathrm{Mn}+\mathrm{Al})$. Change in loading, or net loading, computed as the effluent flow rate multiplied by the

the treatment system removed an average of $47 \%$ of the dissolved iron, $34 \%$ of the dissolved aluminum, and $8 \%$ of the dissolved manganese. Iron accounted for the majority of metals removed by the treatment system, with average influent and effluent loadings of 4.5 and $2.4 \mathrm{t} / \mathrm{y}$, respectively.

Assuming an average unit surface area of $0.19 \mathrm{~cm}^{2} / \mathrm{g}$ for the R-4 size calcitic limestone and $0.13 \mathrm{~cm}^{2} / \mathrm{g}$ for the R-5 size dolomitic limestone (Cravotta et al. 2008), the iron removal rates for the limestone beds in cell $\mathrm{A}$ and cell $\mathrm{B}$ were 0.11 and $0.05\left(\mathrm{~g} / \mathrm{m}^{2}\right) /$ days, respectively, expressed relative to the total exposed surface area of the limestone. Alternatively, the removal rate can be expressed relative to the area of the treatment cells as delineated on a map (Fig. 1). Given a total water-surface area of $1,400 \mathrm{~m}^{2}$ for cell A $\left(500 \mathrm{~m}^{2}\right)$, cell B $\left(500 \mathrm{~m}^{2}\right)$, and the settling pond and wetland combined $\left(400 \mathrm{~m}^{2}\right)$, the areal rate of iron removal varied within the treatment system from $4.3\left(\mathrm{~g} / \mathrm{m}^{2}\right) /$ days for the limestone bed in cell A, $2.0\left(\mathrm{~g} / \mathrm{m}^{2}\right) /$ days for the limestone bed in cell $\mathrm{B}, 0.7\left(\mathrm{~g} / \mathrm{m}^{2}\right) /$ days for the water column (spillway) in cell A, $1.2\left(\mathrm{~g} / \mathrm{m}^{2}\right) /$ days for the water

difference between effluent and influent (Bell AMD) concentration. Cumulative net loading computed as the sum of changes in loading for different components of treatment, in the following order: cell $\mathrm{A}$ spillway, cell A outlet pipe, cell B spillway, and cell B outlet pipe, with the treatment system outflow (Bell 225_m) computed as the difference between effluent and influent loading

column (spillway) in cell $\mathrm{B}$, and $4.4\left(\mathrm{~g} / \mathrm{m}^{2}\right) /$ days for the settling pond and wetland. The average areal removal rate for iron was $4.2\left(\mathrm{~g} / \mathrm{m}^{2}\right) /$ days for the entire treatment system. Throughout the system, the removal rates of manganese and aluminum were smaller than those for iron. These results are consistent with observations of Tarutis et al. (1999) and Kirby et al. (1999) who found that the removal rates of iron and associated metals in aerobic wetlands constructed for treatment of AMD commonly are less than the areal iron-removal rate of $20\left(\mathrm{~g} / \mathrm{m}^{2}\right) /$ days typically considered for sizing of passive systems (e.g. Hedin et al. 1994; U.S. Office of Surface Mining Reclamation and Enforcement 2002).

\section{Discussion: Treatment-System Performance}

Dissolution of limestone and dolomite coupled with the precipitation of iron and aluminum oxides are likely explanations for the changes in loadings of calcium, magnesium, alkalinity, and net acidity within the treatment 
system. Negative values for the SI of calcite $\left(\mathrm{CaCO}_{3}\right)$ and dolomite $\left(\mathrm{CaMg}\left(\mathrm{CO}_{3}\right)_{2}\right)$ indicate these minerals could have dissolved contributing calcium, magnesium, and alkalinity (Table 2). Furthermore, gypsum $\left(\mathrm{CaSO}_{4} \cdot 2 \mathrm{H}_{2} \mathrm{O}\right)$, if present, also could have dissolved providing calcium; however, relatively constant sulfate concentrations and negligible changes in sulfate loadings indicate that gypsum was not an important source of calcium and/or that bacterial sulfate reduction was subordinate to limestone dissolution as a source of alkalinity. Positive values for the SI of ferrihydrite $\left(\mathrm{Fe}(\mathrm{OH})_{3}\right)$ and amorphous $\mathrm{Al}(\mathrm{OH})_{3}$ (Table 2) are consistent with the precipitation of $\mathrm{Fe}(\mathrm{OH})_{3}$ and $\mathrm{Al}(\mathrm{OH})_{3}$ within the treatment system. In contrast, negative values for the SI of various manganese minerals (rhodochrosite, manganite, pyrolusite) (Table 2) are inconsistent with the removal of dissolved manganese within the treatment system. As suggested by Cravotta and Trahan (1999), adsorption of $\mathrm{Mn}^{2+}$ to $\mathrm{Fe}^{\mathrm{III}}$ oxides within the limestone bed could account for the decrease in dissolved manganese concentration.

Small increases in the concentration of magnesium compared to calcium and alkalinity in effluent from the treatment system (Fig. 3c-e) indicate that the dolomitic limestone was relatively unreactive and unimportant as a source of alkalinity compared to the calcitic limestone. This is consistent with results from the laboratory rate models (Cravotta et al. 2008), which indicated that the overall rate of dissolution of dolomitic limestone was less than half that of the calcitic limestone. Furthermore, as previously indicated, conservative transport of sulfate through cells A and B (Figs. 3g, 4e) indicate that sulfate reduction was not active. Hence, the dissolution of calcitic limestone seems to be a predominant mechanism for neutralizing AMD within cells A and B.

Although the effluent from cell A contains lower concentrations of alkalinity and calcium compared to that from cell $\mathrm{B}$, because a larger volume of effluent is transmitted through the treatment beds of cell $\mathrm{A}$, the metal and acidity removal rates for cell A were greater than those for cell $\mathrm{B}$ (Fig. 5). However, the effectiveness of compost as a treatment medium could not be assessed because most of the flow through treatment cell B bypassed that layer. As explained previously, a low-permeability geotextile liner was placed above the dolomitic limestone bed to prevent compost from clogging the underlying R-5 dolomitic limestone bed. Later, the calcitic limestone was partially mixed with the compost and layered above it. Flow down through these layers is impeded by the geotextile liner and, consequently, a large fraction of influent to cell B exits over the spillway (Fig. 3a). Another fraction apparently flows along the sides of the cell to the dolomitic limestone and the underlying discharge pipes. When cell B is flushed, ponded water streams to the sides of the cell and dislodges
$\mathrm{Fe}(\mathrm{OH})_{3}$ coatings from the limestone particles along the edge of the cell (William Reichert, Schuylkill Headwaters Assoc., oral commun., 2006). The effluent that ultimately was sampled from the outlet pipe of cell B represented a mixture of influent that bypassed the treatment media and partly treated effluent that had contact with the dolomitic limestone.

The physical and chemical interactions within the limestone bed warrant close evaluation, particularly considering that the dissolution of limestone and corresponding AMD neutralization rates tend to be faster for small limestone fragments, but the potential for transmitting fluid and flushing the precipitated solids from the system tends to decrease as the limestone size decreases (e.g. Schueck et al. 2004; Weaver et al. 2004). Because potential for exposure of humans and wildlife to metal-rich solids is greater for materials accumulated in ponds and wetlands compared to subsurface or subaqueous limestone beds, designs that accommodate the accumulation of metal-rich solids within the treatment substrate warrant consideration. Specific data on the chemical composition and adhesive characteristics of the metal-rich coatings on limestone surfaces, the potential for recovering accumulated solids from packed limestone beds, and the associated changes in porosity and permeability of different substrates are relevant to determine the effectiveness of passivetreatment systems for attenuating potentially toxic constituents in AMD (e.g. Hammarstrom et al. 2003; Kairies et al. 2005; Santomartino and Webb 2007; Webster et al. 1998; Winland et al. 1991). Ultimately, this information can be used to improve the design and operation of passive systems for effective treatment of AMD.

Tracer injection tests can help indicate the zones of greatest permeability and associated transport through the treatment beds and thereby reconcile differences between the estimated and measured alkalinities of effluent (e.g. Cravotta et al. 2004; Diaz-Goebes and Younger 2004). For example, Cravotta et al. (2004) conducted a tracer test with sodium bromide that demonstrated detention time within a limestone drain was less than half of that computed on the basis of the measured flow rate and assumed saturated volume of the limestone bed (Eq. 7). The short detention times indicated by the tracer were consistent with closedcontainer (cubitainer) test results for short detention times.

\section{Summary and Conclusions}

Iron-laden AMD degrades thousands of kilometers of streams in mining regions worldwide, including hundreds of kilometers of streams in the Southern Anthracite Coalfield of eastern Pennsylvania, USA. The large volume $(16-133 \mathrm{~L} / \mathrm{s})$ and net-acidic character $(\mathrm{pH}$ of 3.6-4.6; net 
acidity $13-35 \mathrm{mg} / \mathrm{L} \mathrm{CaCO}_{3}$ ) of the Bell Discharge, a large source of AMD to the Schuylkill River, supported a remediation strategy using a downflow, flushable limestone bed to facilitate acid neutralization, followed by an aerobic pond and wetland for iron oxidation and removal. Because relatively low concentrations of dissolved metals were typically observed (iron $1.3-13.0 \mathrm{mg} / \mathrm{L}$, manganese 0.9 $1.7 \mathrm{mg} / \mathrm{L}$, aluminum $0.6-1.5 \mathrm{mg} / \mathrm{L}$ ), the need for a compost layer above the limestone was questioned. Hence, with a goal of evaluating the effectiveness of treatment with and without compost, the as-built treatment system split the flow into two treatment cells, one with limestone only and the other with compost over limestone. Instead of using high-purity calcitic limestone for the limestone beds, dolomitic limestone was used to construct the lower bed, and high-purity calcitic limestone was added above the dolomitic limestone to achieve an average $\mathrm{CaCO}_{3}$ content of $85 \mathrm{wt} \%$ for the lower and upper beds combined.

Dissolution reactions between the influent AMD and the limestone in cells $\mathrm{A}$ and $\mathrm{B}$, and iron oxidation and hydrolysis reactions within the water column and on limestone surfaces, caused the effluent from the outlet pipes draining the limestone beds to have: increased $\mathrm{pH}$; increased concentrations of calcium, magnesium, and alkalinity; and decreased concentrations of dissolved aluminum, iron, and manganese compared to the influent or the effluent from the spillways. Continued iron oxidation and hydrolysis reactions within the oxidation pond promoted additional metals removal. On average, the treatment system removed $62 \%$ of the acidity, $47 \%$ of the dissolved iron, $34 \%$ of the dissolved aluminum, and $8 \%$ of the dissolved manganese. The average areal removal rate for iron was $4.2\left(\mathrm{~g} / \mathrm{m}^{2}\right) /$ days for the entire treatment system; the majority was removed within the limestone bed of cell $\mathrm{A}$ and within the final oxidation pond. Although a $0.3 \mathrm{~m}$ thick layer of organic-rich compost was added to the uppermost layer in cell $\mathrm{B}$, a geotextile liner placed between the compost and the underlying dolomitic limestone promoted the overflow and short-circuiting of flow around the sides of cell B. Relatively minor differences in concentrations of magnesium in influent and effluent and greater loadings of calcium and alkalinity from cell A than cell B indicated that dissolution of calcitic limestone in cell A accounted for most of the alkalinity production by the treatment system. Given these observations, one may hypothesize that the treatment system will fail eventually because of depletion of the calcitic limestone in cell A or the clogging of the limestone beds with iron precipitate. The latter problem is currently managed through periodic (monthly) flushing of solids from the treatment cells to a secondary settling pond. However, the depletion of limestone is another matter that can only be remedied by replacing the material that has dissolved. Funding was obtained in September 2007 by the Schuylkill Headwaters Association to remove the geotextile liner from cell $\mathrm{B}$ and add additional calcitic limestone to both cells $\mathrm{A}$ and $\mathrm{B}$.

As demonstrated in this study, treatment of AMD through submerged limestone beds can effectively neutralize acid and remove dissolved iron and other metals from AMD while moderating the temperature of the effluent. The performance of the Bell Discharge treatment system and, possibly, other passive-treatment systems for treatment of net-acidic AMD may be improved by using high purity-calcitic limestone to increase $\mathrm{pH}$, add alkalinity, and accelerate iron oxidation. Nevertheless, the rapid dissolution of calcitic limestone can lead to a recurring need for its replenishment and/or the limestone beds can become clogged with $\mathrm{Fe}(\mathrm{OH})_{3}$. In contrast, the relative stability of the dolomitic limestone and the use of this material as a base substrate could be beneficial over the long-term. Because it dissolves slowly compared to the overlying calcitic limestone, the dolomitic limestone could be expected to maintain its high transmissivity and integrity in the vicinity of the perforated pipe flushing system, while providing a moderate benefit as a secondary source of alkalinity.

Although the interaction between limestone and AMD with relatively low concentrations of dissolved metals could be evaluated in this study, the effectiveness of compost as a treatment medium could not be assessed because most of the flow through treatment cell B bypassed that layer. Other studies have demonstrated that the incorporation of organicrich compost and its oxidation within a limestone-based treatment system can enhance alkalinity production because of $\mathrm{CO}_{2}$ production and associated interaction with the limestone. The compost may be particularly effective for treatment of AMD with high concentrations of dissolved ferric iron and aluminum. Comparable effluent quality from the treatments with compost plus limestone (cell B) and limestone only (cell A) in this study resulted because the geotextile liner that was placed beneath the compost layer impeded the flow of water through the compost to the limestone. Hydraulic effects would need to be considered before placement of a low-permeability layer among other layers with greater permeabilities. These considerations should address both the ability of the system to transmit water and the detention time within the substrate that is intended to be permeable and reactive.

Improved designs and their implementation are warranted to enhance alkalinity production and metals removal while minimizing short-circuiting, clogging, and other operation and maintenance problems associated with passive treatment by limestone beds. Data generally are lacking on transport rates and the effectiveness of flushing of solids and long-term maintenance of limestone-based passive-treatment systems. Tracer tests may help document 
transport rates and zones of short-circuiting or clogging within the treatment media. Data on the conditions of formation of specific minerals and their potential to foul treatment systems would be needed to determine if burial, the addition of compost, and/or regular flushing will be effective measures to maintain system performance. Furthermore, sustained monitoring of the flow, water quality, and aquatic ecology at AMD treatment sites and associated streams would be needed to produce data on the long-term performance and environmental effects of a treatment system(s).

Acknowledgments This project was conducted by the U.S. Geological Survey (USGS) in cooperation with the Schuylkill Conservation District (SCD) and the Pennsylvania Department of Environmental Protection (PaDEP). The authors gratefully acknowledge assistance from USGS colleagues Michael Bilger and Robin Brightbill for biological monitoring and Robert R. Seal and Nadine Piatak for analytical support. Todd Wood of the PaDEP Bureau of Abandoned Mine Reclamation designed the conceptual treatment system and Clayton Bubeck of Rettew Associates completed the final engineering drawings and detailed plans for construction. William Reichert of SCD, Ryan Koch of Natural Resources Conservation Service, and Thomas Davidock of Delaware Valley Earth Force documented construction activities and maintained the treatment system during the study. The manuscript benefited from reviews by Kevin Breen, Daniel Hippe, Robert Runkel, and Dorothy Tepper of USGS and two anonymous reviewers. Any use of trade, firm, or product names is for descriptive purposes only and does not imply endorsement by the U.S. Government.

\section{References}

American Public Health Association (1998a) Alkalinity (2320)/ titration method. In: Clesceri LS, Greenberg AE, Eaton AD (eds) Standard methods for the examination of water and wastewater, 20th edn. American Public Health Assoc, Washington, pp 2.26-2.30

American Public Health Association (1998b) Acidity (2310)/titration method. In: Clesceri LS, Greenberg AE, Eaton AD (eds) Standard methods for the examination of water and wastewater, 20th edn. American Public Health Assoc, Washington, pp 2.24-2.26

Amos PW, Younger PL (2003) Substrate characterization for a subsurface reactive barrier to treat colliery spoil leachate. Water Res 37:108-120

Appelo CAJ, Postma D (1993) Geochemistry, groundwater and pollution. AA Balkema Publ, Brookfield, $536 \mathrm{pp}$

Ball JW, Nordstrom DK (1991) User's manual for WATEQ4F with revised data base: USGS Open-File Report 91-183, http:// www.brr.cr.usgs.gov/projects/GWC_chemtherm/pubs/wq4fdoc. pdf, $189 \mathrm{pp}$

Barbour MT, Gerritsen J, Snyder BD, Stribling JB (1999) Rapid bioassessment protocols for use in streams and wadeable riversperiphyton, benthic macroinvertebrates, and fish, 2nd edn, chap. 11. US EPA 841-B-99-002, 4 appendices (http://www.epa.gov/ OWOW/monitoring/techmon.html)

Berg TM, Edmunds WE, Geyer AR, Glover AD, Hoskins DM, MacLachlan DB, Root SI, Sevon WD, Socolow AA (1980) Geologic map of Pennsylvania: PA Geol Survey, 4th Series, Map \#1, scale 1:2,500,000, 3 sheets
Bigham JM, Nordstrom DK (2000) Iron and aluminum hydroxysulfate minerals from acid sulfate waters. In: Jambor JL, Alpers CN, Nordstrom DK (eds) Sulfate minerals, crystallography, geochemistry and environmental significance. Mineral Soc Am Rev Mineral Geochem 40:351-403

Brodie GA, Britt CR, Tomaszewski TM, Taylor HN (1991) Use of passive anoxic limestone drains to enhance performance of acid drainage treatment wetlands. In: Proceedings of the 1991 national meeting of the american soc for surface mining and reclamation, pp 211-228

Butler RL, Cooper EL, Crawford JK, Hales DC, Kimmel WG, Wagner CC (1973) Fish and food organisms in acid mine waters of Pennsylvania. US EPA-R3-73-032, $158 \mathrm{pp}$

Commonwealth of Pennsylvania (2002) Water quality standards. Pennsylvania Code, Title 25, chap. 93. Environmental Protection, Harrisburg, PA, USA, pp 93.1-93.226

Cravotta CA III (2007) Dissolved metals and associated constituents in abandoned coal-mine discharges, Pennsylvania, USA: 1. Constituent concentrations and correlations. Appl Geochem http://dx.doi.org/10.1016/j.apgeochem.2007.10.011

Cravotta CA III (2003) Size and performance of anoxic limestone drains to neutralize acidic mine drainage. J Environ Qual 32:1277-1289

Cravotta CA III, Brady KBC, Rose AW, Douds JB (1999) Frequency distribution of the $\mathrm{pH}$ of coal-mine drainage in Pennsylvania. In: Morganwalp DW, Buxton H (eds) USGS toxic substances hydrology program-proceedings of the technical meeting, USGS Water-Resources Investigations Report 99-4018A, pp 313-324

Cravotta CA III, Trahan MK (1999) Limestone drains to increase $\mathrm{pH}$ and remove dissolved metals from acidic mine drainage. Appl Geochem 14:581-606

Cravotta CA III, Ward SJ, Hammarstrom JM (2008) Downflow limestone beds for treatment of net-acidic, oxic, iron-laden drainage from a flooded anthracite mine, Pennsylvania, USA: 2. Laboratory evaluation. Mine Water Environ (this issue)

Cravotta CA III, Ward SJ, Koury DJ, Koch RD (2004) Optimization of limestone drains for long-term treatment of acidic mine drainage, Swatara Creek Basin, Schuylkill County, PA. In: Proceedings of the 2004 national meeting of the American soc of mining and reclamation and the 25 th $\mathrm{WV}$ surface mine drainage task force, pp 366-411

Cravotta CA III, Watzlaf GR (2002) Design and performance of limestone drains to increase $\mathrm{pH}$ and remove dissolved metals from acidic mine drainage. In: Naftz DL, Morrison SJ, Fuller CC, Davis JA (eds) Handbook of groundwater remediation using permeable reactive barriers-applications to radionuclides, trace metals, and nutrients. Academic Press, San Diego, pp 19-66

Crock JG, Arbogast BF, Lamothe PJ (1999) Laboratory methods for the analysis of environmental samples. In: Plumlee GS, Logsdon MJ (eds) The environmental geochemistry of mineral depositspart A, vol 6A. Processes, Techniques, and Health Issues, Soc of Economic Geologists, Reviews in Economic Geology, pp 265-287

Demchak J, Morrow T, Skousen J (2001) Treatment of acid mine drainage by four vertical flow wetlands in Pennsylvania. Geochem Explor Environ Anal 1:71-80

Drever JI (1997) The geochemistry of natural waters-surface and groundwater environments, 3rd edn. Prentice-Hall, Inc, Englewood Cliffs, $436 \mathrm{pp}$

Diaz-Goebes M, Younger PL (2004) A simple analytical model for interpretation of tracer tests in two-domain subsurface flow systems. Mine Water Environ 23:138-143

Eggleston JR, Kehn TM, Wood GH Jr (1999) Anthracite. In: Schultz $\mathrm{CH}$ (ed) The geology of Pennsylvania. PA Geological Survey. 4th series, Special Publ 1, pp 458-469 
Fishman MJ, Friedman LC (eds) (1989) Methods for determination of inorganic substances in water and fluvial sediments. USGS Techniques of Water-Resources Investigations, book 5, chap. A1, $545 \mathrm{pp}$

Growitz DJ, Reed LA, Beard MM (1985) Reconnaissance of mine drainage in the coal fields of eastern Pennsylvanian. USGS Water-Resources Investigations Report 83-4274, 54 pp

Hammarstrom JM, Sibrell PL, Belkin HE (2003) Characterization of limestone reacted with acid-mine drainage in a pulsed limestone bed treatment system at the friendship hill national historic site, Pennsylvania, USA. Appl Geochem 18:1705-1721

Hedin RS, Nairn RW, Kleinmann RLP (1994) Passive treatment of coal mine drainage. USBM IC 9389, $35 \mathrm{pp}$

Hedin RS, Watzlaf GR (1994) The effects of anoxic limestone drains on mine water chemistry. USBM SP 06A, pp 185-194

Herlihy AT, Kaufmann PR, Mitch ME, Brown DD (1990) Regional estimates of acid mine drainage impact on streams in the midAtlantic and southeastern United States. Water Air Soil Pollut 50:91-107

Herman JS, White WB (1985) Dissolution kinetics of dolomiteeffects of lithology and fluid flow velocity. Geochim Cosmochim Acta 49:2017-2026

Hyman DM, Watzlaf GR (1997) Metals and other components of coal mine drainage as related to aquatic life standards. In: Proceeedings of the 1997 national meeting of the american soc for surface mining and reclamation, Austin, Texas, pp 531-545

Jage CR, Zipper CE, Noble R (2001) Factors affecting alkalinity generation by successive alkalinity-producing systems: regression analysis. J Environ Qual 30:1015-1022

Jones EJP Nadeau TL, Voytek MA, Landa ER (2006) Role of microbial iron reduction in the dissolution of iron hydroxysulfate minerals. J Geophys Res 111:G01012, 6 pp

Kairies CL, Capo RC, Watzlaf GR (2005) Chemical and physical properties of iron hydroxide precipitates associated with passively treated coal mine drainage in the Bituminous Region of Pennsylvania and Maryland. Appl Geochem 20:1445-1460

Kepler DA, McCleary EC (1994) Successive alkalinity producing systems (SAP's) for the treatment of acidic mine drainage: USBM SP 06A, pp 195-204

Kirby CS, Cravotta CA III (2005a) Net alkalinity and net acidity 1: theoretical considerations. Appl Geochem 20:1920-1940

Kirby CS, Cravotta CA III (2005b) Net alkalinity and net acidity 2: practical considerations. Appl Geochem 20:1941-1964

Kirby CS, Thomas HM, Southam G, Donald R (1999) Relative contributions of abiotic and biological factors in Fe(II) oxidation in mine drainage. Appl Geochem 14:511-530

L. Robert Kimball and Associates Inc. (2000) Upper Schuylkill River Tributaries Assessment Report

Lovley DR (1991) Dissimilatory Fe(III) and Mn(IV) reduction. Microbiol Rev 55:259-287

Lovley DR, Phillips EJP (1986) Organic matter mineralization with reduction of ferric iron in anaerobic sediments. Appl Environ Microbiol 51:683-689

Meador MR, Cuffney TF, Gurtz ME (1993) Methods for sampling fish communities as part of the National Water-Quality Assessment Program. USGS Open-File Report 93-104, 40 pp

Nordstrom DK (1977) Thermochemical redox equilibria of Zobell's solution. Geochim Cosmochim Acta 41:1835-1841

Nordstrom DK (2000) Advances in the hydrochemistry and microbiology of acid mine waters. Int Geol Rev 42:499-515

Pennsylvania Dept of Environmental Protection (2000) Erosion and sediment pollution control program manual. PA DEP, Bureau of Watershed Mgmt, Doc \# 363-2134-008, tables 9 and 10A, Harrisburg, PA, USA, $180 \mathrm{pp}$

Pennsylvania Dept of Environmental Protection (2003) Watershed Restoration Action Strategy (WRAS) Subbasin 06A Upper
Schuylkill River Watershed Schuylkill, Carbon, and Berks Counties, PA. http://www.dep.state.pa.us/dep/deputate/watermgt/ wc/Subjects/Nonpointsourcepollution/Initiatives/Wraslist.htm, $16 \mathrm{pp}$

Pennsylvania Dept of Environmental Protection (2004) Integrated list of all waters. http://www.dep.state.pa.us/dep/deputate/watermgt/ wqp/wqstandards/303d-Report.htm, $1807 \mathrm{pp}$

PIRAMID Consortium (2003) Engineering guidelines for the passive remediation of acidic and/or metalliferous mine drainage and similar wastewaters. European Commission 5th Framework RTD Project no. EVK1-CT-1999-000021 "Passive in-situ remediation of acidic mine/industrial drainage" (PIRAMID). University of Newcastle Upon Tyne, Newcastle Upon Tyne UK, $166 \mathrm{pp} \mathrm{http://www.ncl.ac.uk/environment/research/documents/}$ PIRAMIDGuidelinesv1.0.pdf

Rantz SE et al (1982a) Measurement and computation of streamflow1. Measurement of stage and discharge, vol 1. USGS WaterSupply Paper 2175, 284 pp

Rantz SE et al (1982b) Measurement and computation of streamflow2. Computation of discharge, vol 2. USGS Water-Supply Paper $2175,631 \mathrm{pp}$

Robbins EI, Nord GL, Savela CE, Eddy J, Livi KJT, Gullett CD, Nordstrom DK, Chou I-M, Briggs KM (1996) Microbial and mineralogical analysis of aluminum-rich precipitates that occlude porosity in a failed anoxic limestone drain, Monongalia County, West Virginia. In: Chiang S-H (ed) Proceedings of the 13th international Pittsburgh coal conf, vol 2. Reed \& Witting Co, Pittsburgh, pp 761-767

Robbins EI, Cravotta CA III, Savela CE, Nord GL Jr (1999) Hydrobiogeochemical interactions in "anoxic" limestone drains for neutralization of acidic mine drainage. Fuel 78:259-270

Rose AW (2004) Vertical flow systems - effects of time and acidity relations. In: Proceedings of the 2004 national meeting of the american soc of mining and reclamation and the 25th WV surface mine drainage task force, pp 1595-1603

Rose AW, Cravotta CA III (1998) Geochemistry of coal-mine drainage. In: Brady KBC, Smith MW, Schueck JH (eds) The prediction and prevention of acid drainage from surface coal mines in Pennsylvania. PA Dept of Environmental Protection, Harrisburg, PA, USA, 5600-BK-DEP2256, p 1.1-1.22

Santomartino S, Webb JA (2007) Estimating the longevity of limestone drains in treating acid mine drainage containing high concentrations of iron. Appl Geochem 22:2344-2361

Schueck JH, Helfrich DR, Fromell DJ (2004) Limestone upflow pond with siphon discharge design considerations-a simple solution to high volume, high metals AMD discharges. In: Proceedings of the 6th annual statewide conf on abandoned mine reclamation, Indiana PA, Western PA Coalition for Abandoned Mine Reclamation, Bedford, PA, USA, 23 pp

Skousen JG, Rose AW, Geidel G, Foreman J, Evans R, Hellier W (1998) Handbook of technologies for avoidance and remediation of acid mine drainage. National Mine Land Reclamation Center, Morgantown, $131 \mathrm{pp}$

Sterner PL, Skousen JJ, Donovan JJ (1998) Geochemistry of laboratory anoxic limestone drains. In: Proceedings of the 1998 national meeting of the american soc for surface mining and reclamation, pp 214-234

Tarutis WJ Jr, Stark LR, Williams FM (1999) Sizing and performance estimation of coal mine drainage wetlands. Ecol Eng 12:353-372

Thomas RC, Romanek CS (2002a) Passive treatment of low-pH, ferric dominated acid rock drainage in a vertical flow wetlandI: acidity neutralization and alkalinity generation. In: Proceedings of the 19th annual meeting of american soc of mining and reclamation, Lexington, Kentucky, pp 723-751

Thomas RC, Romanek CS (2002b) Passive treatment of low-pH, ferric dominated acid rock drainage in a vertical flow wetland- 
II. Metal removal. In: Proceedings of the 19th annual meeting of american soc of mining and reclamation, Lexington, KY, USA, pp 752-775

Todorova SG, Siegel DI, Costello AM (2005) Microbial Fe(III) reduction in a minerotrophic wetland-geochemical controls and involvement in organic matter decomposition. Appl Geochem 20:1120-1130

Turner D, McCoy D (1990) Anoxic alkaline drain treatment system, a low cost acid mine drainage treatment alternative. In: Graves DH, DeVore RW (eds) Proceedings of the 1990 symp on surface mining hydrology, sedimentology and reclamation. University of KY, Lexington, pp 73-75

U.S. Environmental Protection Agency (2002) National recommended water quality criteria-2002. US EPA 822-R-02-047, $33 \mathrm{pp}$

U.S. Environmental Protection Agency (2006) Areas impacted by acidification-acid mine drainage and acid deposition remain significant problems in region III. US EPA, accessed May 15, 2006 at http://www.epa.gov/Region3/acidification/r3_acidifcation.htm

U.S. Geological Survey (1997 to present) National field manual for the collection of water-quality data. USGS Techniques of WaterResources Investigations, book 9, chap. A1-A9. http://pubs. water.usgs.gov/twri9A

U.S. Geological Survey (2007) Water Quality Samples for Pennsylvania. USGS Water Resources, National Water Information System, Web interface: http://nwis.waterdata.usgs.gov/pa/nwis/ qwdata

U.S. Office of Surface Mining Reclamation and Enforcement (2002) AMDTreat 3.1, Washington, DC, US OSMRE, accessed June 15, 2003 at http://amd.osmre.gov

Watzlaf GR (1997) Passive treatment of acid mine drainage in downflow limestone systems. In: Proceedings of the 1997 national meeting of the american soc for surface mining and reclamation, May 10-15, 1997, Austin, Texas, American Soc for Surface Mining and Reclamation, pp 611-622

Watzlaf GR, Schroeder KT, Kairies C (2000) Long-term performance of alkalinity-producing passive systems for the treatment of mine drainage. In: Proceedings of the 2000 national meeting of the american soc for surface mining and reclamation, pp 262-274

Watzlaf GR, Schroeder KT, Kleinmann RLP, Kairies CL, Nairn RW (2004) The passive treatment of coal mine drainage. US DOE/NETL-2004/1202 http://www.netl.doe.gov/technologies/ coalpower/ewr/water/pdfs/Passive\%20Treatment.pdf

Way JH (1999) Appalachian mountain section of the ridge and valley province. In: Schultz CH (ed) The geology of Pennsylvania. PA Geological Survey, 4th series, Special Publ 1, pp 352-361

Weaver KR, Lagnese KM, Hedin RS (2004) Technology and design advances in passive treatment system flushing. In: Proceedings of the 2004 national meeting of the american soc of mining and reclamation and the 25th west Virginia surface mine drainage task force, April 18-24, 2004, pp 1974-1989

Webster JG, Swedlund PJ, Webster KS (1998) Trace metal adsorption onto an acid mine drainage iron(III) oxy hydroxy sulfate. Environ Sci Technol 32:1361-1368

Williams DJ, Bigham JM, Cravotta CA III, Traina SJ, Anderson JE, Lyon G (2002) Assessing mine drainage $\mathrm{pH}$ from the color and spectral reflectance of chemical precipitates. Appl Geochem 17:1273-1286

Winland RL, Traina SJ, Bigham JM (1991) Chemical composition of ochreous precipitates from Ohio coal mine drainage. J Environ Qual 20:452-460

Wood CR (1996) Water quality of large discharges from mines in the anthracite region of eastern Pennsylvania. USGS WaterResources Investigations Report 95-4243, 69 pp

Wood GH Jr, Kehn TM, Eggleston JR (1986) Deposition and structural history of the Pennsylvania Anthracite region. In: Lyons PC, Rice CL (eds) Paleoenvironmental and Tectonic Controls in Coal-Forming Basins of the United States: Geol Soc America Special Paper 210, pp 31-47

Wood WW (1976) Guidelines for the collection and field analysis of ground-water samples for selected unstable constituents: USGS Techniques of Water-Resources Investigations, book 1, chap. D2, $24 \mathrm{pp}$ 